Review

\title{
Low-Carbon Development for the Iron and Steel Industry in China and the World: Status Quo, Future Vision, and Key Actions
}

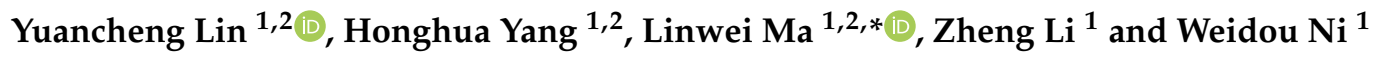 \\ 1 Tsinghua-BP Clean Energy Research and Education Centre, State Key Laboratory of Power Systems, \\ Department of Energy and Power Engineering, Tsinghua University, Beijing 100084, China; \\ linyc19@mails.tsinghua.edu.cn (Y.L.); yhh18@mails.tsinghua.edu.cn (H.Y.); lz-dte@tsinghua.edu.cn (Z.L.); \\ niwd@tsinghua.edu.cn (W.N.) \\ 2 Tsinghua-Rio Tinto Joint Research Centre for Resources, Energy and Sustainable Development, \\ Laboratory for Low Carbon Energy, Tsinghua University, Beijing 100084, China \\ * Correspondence: malinwei@tsinghua.edu.cn
}

Citation: Lin, Y.; Yang, H.; Ma, L.; Li, Z.; Ni, W. Low-Carbon Development for the Iron and Steel Industry in China and the World: Status Quo, Future Vision, and Key Actions. Sustainability 2021, 13, 12548. https://doi.org/10.3390/su132212548

Academic Editor: Grigorios

L. Kyriakopoulos

Received: 16 October 2021

Accepted: 10 November 2021

Published: 13 November 2021

Publisher's Note: MDPI stays neutral with regard to jurisdictional claims in published maps and institutional affiliations.

Copyright: (c) 2021 by the authors. Licensee MDPI, Basel, Switzerland. This article is an open access article distributed under the terms and conditions of the Creative Commons Attribution (CC BY) license (https:/ / creativecommons.org/licenses/by/ $4.0 /)$.

\begin{abstract}
The low-carbon development of China's iron and steel industry (ISI) is important but challenging work for the attainment of China's carbon neutrality by 2060 . However, most previous studies related to the low-carbon development of China's ISI are fragmented from different views such as production-side mitigation, demand-side mitigation, or mitigation technologies. Additionally, there is still a lack of a comprehensive overview of the long-term pathway to the low-carbon development of China's ISI. To respond to this gap and to contribute to better guide policymaking in China, this paper conducted a timely and comprehensive review following the technology roadmap framework covering the status quo, future vision, and key actions of the low-carbon development of the world and China's ISI. First, this paper provides an overview of the technology roadmap of low-carbon development around the main steel production countries in the world. Second, the potential for key decarbonization actions available for China's ISI are evaluated in detail. Third, policy and research recommendations are put forward for the future low-carbon development of China's ISI. Through this comprehensive review, four key actions can be applied to the low-carbon development of China's ISI: improving energy efficiency, shifting to Scrap/EAF route, promoting material efficiency strategy, and deploying radical innovation technologies.
\end{abstract}

Keywords: China; iron and steel industry; low-carbon development; technology roadmap

\section{Introduction}

An active response to climate change has become a global consensus. The Paris Agreement announced the global climate goal of curbing $\mathrm{CO}_{2}$ emissions growth to hold the global average temperature rise within $2{ }^{\circ} \mathrm{C}$ above pre-industrial levels by 2100 [1]. Following this announcement, governments around the world have successively released their ambitious climate goals committed to carbon neutrality. As the world's largest carbon emitter [2], China has scaled up its intended Nationally Determined Contributions (NDC), aiming to have $\mathrm{CO}_{2}$ emissions peak before 2030 and to achieve carbon neutrality before 2060 [3].

As a typical "hard-to-abate" sector with the most energy- and emissions-intensive production, the low-carbon development of the iron and steel industry (ISI) is important but challenging for achieving climate goals. Steel is a basic material supporting economic development, having unique properties: strength, formability, and many functions. Looking around the world, no country has achieved high per capita incomes without substantially increasing steel consumption per capita [4]. On the other hand, the ISI is the largest $\mathrm{CO}_{2}$ emitter among heavy industries. As stated by the International Energy Agency (IEA), it emitted 2.6 Gt of direct $\mathrm{CO}_{2}$ emissions in 2019, accounting for approximately one-quarter of 
industrial $\mathrm{CO}_{2}$ emissions and 7\% of total energy system emissions [5]. Besides, given that the coke from coal coking is used as the main reduction agent in the ironmaking process, coal has been the dominant energy input for the ISI, accounting for almost three-quarters of the total energy inputs, making $\mathrm{CO}_{2}$ emissions hard to abate [5].

The low-carbon development of China's ISI is burdened with arduous tasks. In the past years, steel has provided a good basis for the developing economy in China, supporting building and infrastructure construction, machinery manufacturing, etc. [6]. With the rapid development of industrialization and urbanization, China has been the world's largest steel producer, with $996 \mathrm{Mt}$ and 53\% of the global production share in 2019 [7]. On the other hand, China's ISI has consumed large quantities of fossil fuels and related $\mathrm{CO}_{2}$ emissions. Estimations have shown that it has been the main $\mathrm{CO}_{2}$ emitter in China, contributing around $20 \%$ of total energy-related $\mathrm{CO}_{2}$ emissions [8].

However, the long-term low-carbon development pathway of China's ISI is still unclear. In recent years, policies related to China's ISI have mostly focused on energy conservation $[9,10]$ and ultra-low emissions of pollutants [11-13], which has indeed brought a positive impact on the reduction of energy consumption and pollutant emissions. Under China's commitment to carbon neutrality by 2060, low-carbon development will be the new focus and the urgent target for China's ISI. The latest research related to $\mathrm{CO}_{2}$ emission reduction in China's ISI has been conducted from the view of supply-side mitigation, for example, the optimization of energy use [14], and $\mathrm{CO}_{2}$ recycling from steelmaking systems [15]; demand-side mitigation, such as the recycling and reuse of scrap steel [16]; and mitigation technology options, including hydrogen-based steelmaking technology $[17,18]$. However, most of these studies are fragmented from different views and cannot provide a comprehensive overview for the long-term policymaking of the low-carbon development pathway of China's ISI.

To respond to this gap and to better guide policymaking in China, this paper provides a timely and comprehensive review following the technology roadmap framework covering the status quo, future vision, and key actions of low-carbon development pathways for ISI in China and around the world, and tries to point out key priorities for low-carbon development in China's ISI, as outlined in Figure 1. More specifically, the main contributions of this paper are listed as follows:

- This paper provides a timely and comprehensive overview of the low-carbon technology roadmap around the main steel production countries in the world, covering status quo, future vision, and key actions.

- Referring to the low-carbon technology roadmaps published by other steel-producing countries and to the actual situation in China, key actions available for the decarbonization of China's ISI are evaluated one by one, including improving energy efficiency, shifting to Scrap/EAF route, promoting material efficiency strategy, and deploying radical innovation technologies.

- Suggestions on policy recommendations and next-step research priorities are given for the low-carbon development of China's ISI.

The layout of the present paper is organized as follows: Section 2 introduces the framework of the technology roadmap. Section 3 briefly describes the iron and steel metallurgical process. Section 4 provides an overview of the low-carbon technology roadmap around the global ISI. Section 5 comprehensively reviews the status quo and vision, and evaluates the potential of key actions towards a low-carbon ISI in China. 


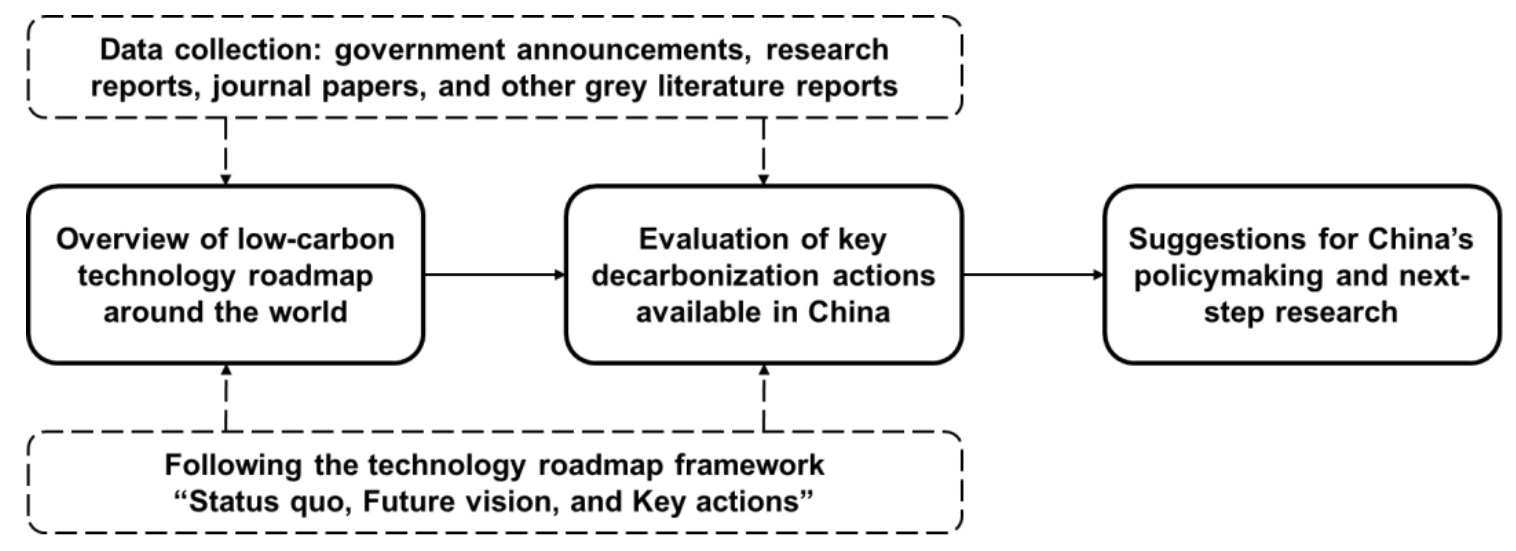

Figure 1. The outline of this paper.

\section{The Technology Roadmap Framework}

The technology roadmap is a widely used strategic planning tool that describes the steps required to achieve desired outcomes or goals for an organization [19]. It was earlier proposed by Robert Galvin [20] and initially applied in business management [21] and product innovation [22]. In recent years, the technology roadmap has been widely applied in the energy field [23], such as the development of bioenergy exploitation [24], China's traction battery [25], renewable natural gas [26], and the carbon neutral industrial park [27].

The structure of a technology roadmap is very flexible in order to adapt to various strategy and innovation contexts [28]. As summarized by Phaal and Muller [28], three key questions must be addressed in an effective technology roadmap: Where are we now? Where do we want to go? How can we get there?

Following this technology roadmap guideline, this paper reviewed the low-carbon development of the ISI from the views of the current status quo, future vision, and key actions, aiming to answer the following three questions. In addition, considering the actual situations and the focus of previous studies, key actions were reviewed from the three dimensions of the supply-side, demand-side, and policy-side. The review framework used in this study is illustrated in Figure 2.

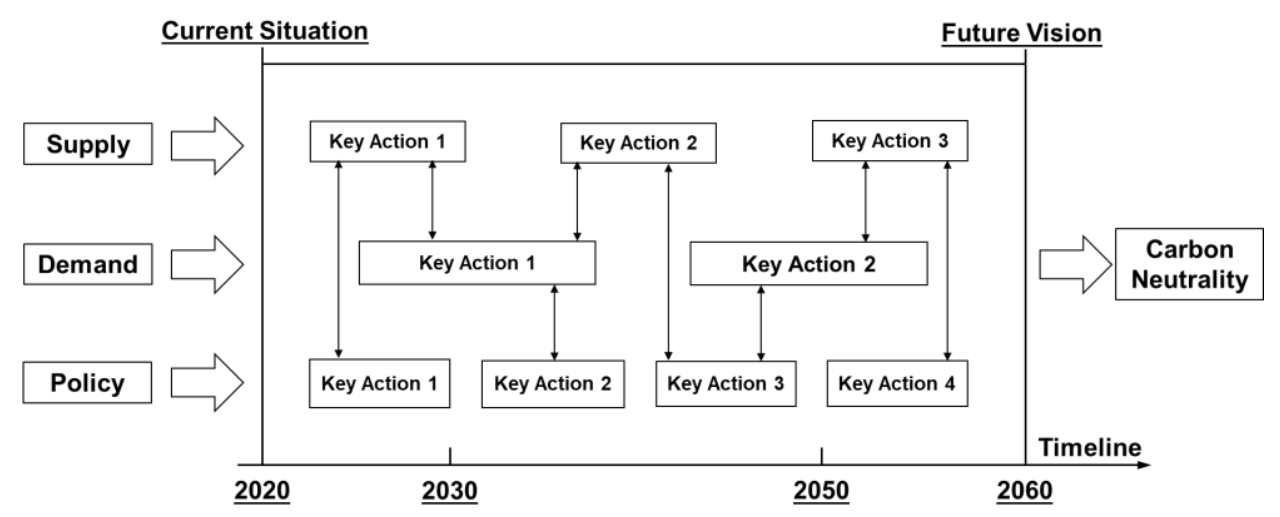

Figure 2. The review framework used in this study based on technology roadmap guideline.

- What is the current status of $\mathrm{CO}_{2}$ emissions for the global and China's the ISI?

- What is the future vision set for the low-carbon development of the ISI in China and the world?

- How can the ISI, in China and the world, achieve the low-carbon development vision? 


\section{Iron and Steel Metallurgical Process}

Steel is produced from chemically reduced iron ore or the recycled scrap steel after several processing steps, consisting of ironmaking, primary and secondary steelmaking, casting and hot rolling, and fabrication processes [29].

$\mathrm{CO}_{2}$ emissions of the ISI are often generated from two main sources [5]: (1) energyrelated emissions from energy consumption; (2) process emissions from some raw materials, such as limestone used for impurity removal. The energy-related emissions account for $90 \%$ of the total $\mathrm{CO}_{2}$ emissions of the ISI [5], which can be further divided into (1) direct energy-related emissions from energy combustion alone, such as coke and natural gas, and (2) indirect energy-related emissions from electricity consumption.

Figure 3 is an overview of various routes of iron and steel production: the blast furnace/basic oxygen furnace route (BF/BOF route); the scrap steel/electric arc furnace route (scrap/EAF route); the direct reduction iron route (DRI route); and the smelting reduction iron route (SRI route) [30,31]. Table 1 lists the world steel production by different routes in 2019. Brief descriptions of these four routes are listed as follows:

- The $\mathrm{BF} / \mathrm{BOF}$ route is the most common primary steel production route around the world, accounting for a $72 \%$ share of the world's steel production, as listed in Table 1. It is a two-stage process composed of ironmaking in the blast furnace (BF) and steelmaking in the basic oxygen furnace (BOF). First, the iron ore is sintered or pelletized and then fed to the blast furnace. Second, in the blast furnace (BF), iron ore is reduced to pig iron with coke. Then, in the basic oxygen furnace (BOF), the pig iron is refined into crude steel, where impurities (such as $\mathrm{C}$ and $\mathrm{Si}$ ) are removed under high purity oxygen at a temperature above $1600{ }^{\circ} \mathrm{C}$. The blast furnace (BF) is the most energy-intensive step in the $\mathrm{BF} / \mathrm{BOF}$ route, and generates large quantities of $\mathrm{CO}_{2}$, accounting for approximately $72 \%$ of the total energy expended in the BF/BOF route, or around $16 \mathrm{GJ}$ per ton of crude steel [32].

- The scrap/EAF route is the main secondary steel-production route, accounting for a $28 \%$ share of the world's steel production, as listed in Table 1 . The recycled scrap steel is melted by high-power electric arcs to produce crude steel in the electric arc furnace (EAF) at a very high temperature of above $4000{ }^{\circ} \mathrm{C}$. The scrap/EAF route uses recycled scrap steel to produce crude steel and does not require coke as a reducing agent, which consumes less energy and emits significantly lower $\mathrm{CO}_{2}$ than the $\mathrm{BF} / \mathrm{BOF}$ route. As evaluated by Zhang, et al., [33], the average energy consumed in the scrap/EAF route is about $0.30 \mathrm{tce} / \mathrm{tcs}$ (tonne coal equivalent per ton of crude steel), whereas that for the $\mathrm{BF} / \mathrm{BOF}$ route is 0.50 tce/tcs. As for $\mathrm{CO}_{2}$ emission, the steel produced by the scrap/EAF route leads to $0.6 \mathrm{tCO}_{2} / \mathrm{tcs}$ (ton $\mathrm{CO}_{2}$ per tonne of crude steel), while the integrated BF/BOF route emits $2.1 \mathrm{tCO}_{2} / \mathrm{tcs}$. Furthermore, if the electricity used in the scrap/EAF route can be generated by net-zero emission renewable energy sources, the scrap/EAF route will be deeply decarbonized. Hence, the scrap/EAF route is considered a promising steel-production route with huge $\mathrm{CO}_{2}$ emission reduction potential.

- The Direct Reduced Iron (DRI)/EAF route is an alternative to the primary steel production of the $\mathrm{BF} / \mathrm{BOF}$ route. In the direct reduction process, the iron ore is reduced by natural gas (or coal in some cases) directly to iron in its solid state at a low temperature. Unlike in the blast furnace (BF), the iron ore is not melted, and the removal of oxygen leaves large numbers of micropores in the direct reduced iron, also called "sponge iron". Direct reduced iron generally has higher purity than pig iron from the blast furnace (BF) process, and is a better raw material for electric arc furnaces (EAF), usable as an alternative to scrap steel.

- Smelting reduced iron (SRI) is an alternative to the blast furnace (BF) and is developed to overcome the consumption of energy-intensive coke. In this process, the iron ore is reduced in its molten state at a very high temperature, resulting in hot liquid iron. Unlike in the blast furnace (BF), the coal is gasified and used as the reducing agent. 
Several SRI processes have been commercially proven, such as HIsarna, COREX, FINEX, and the ITmK3 project [30].

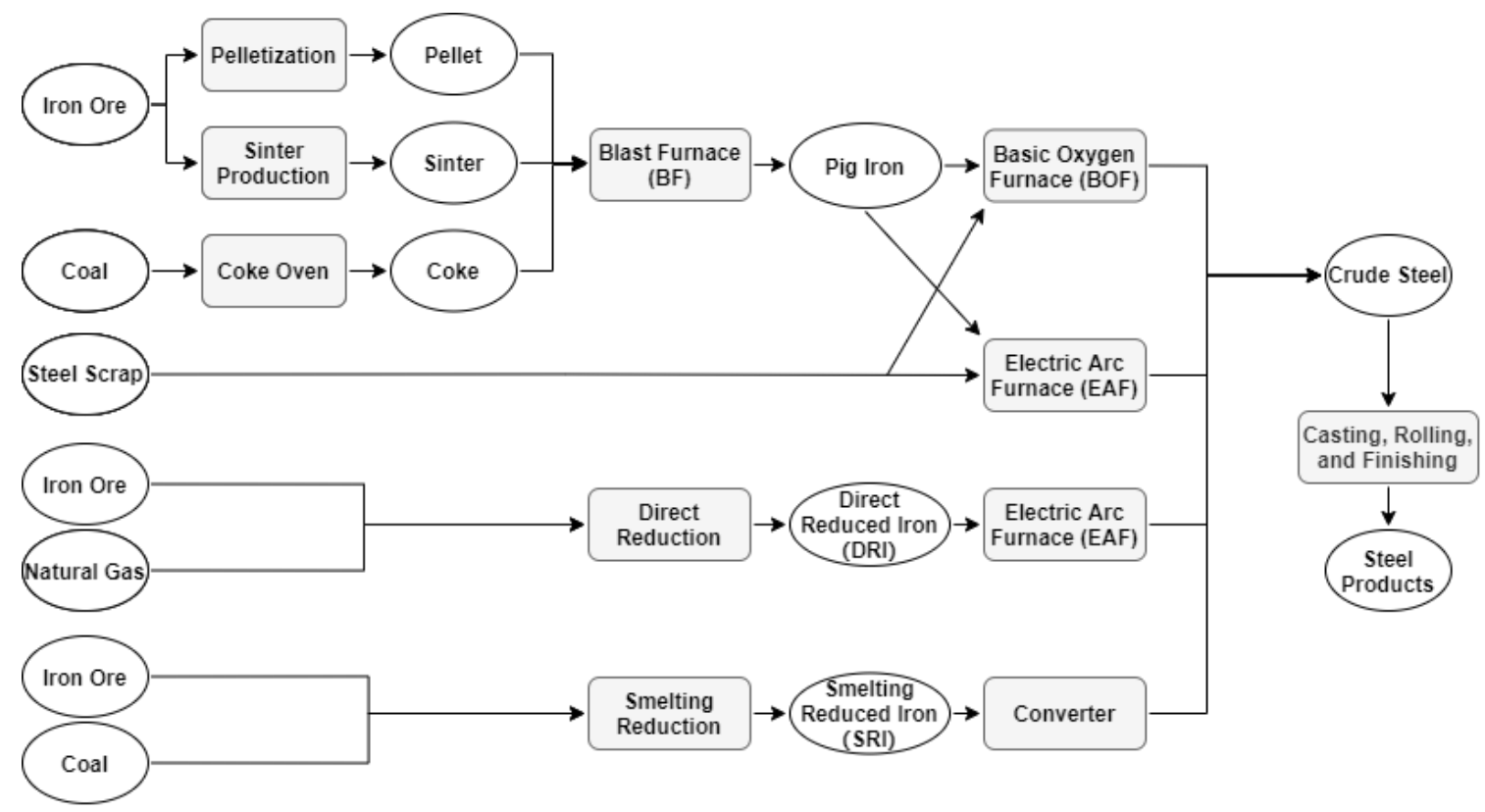

Figure 3. Flow diagrams of main routes of the iron and steel production.

Table 1. World steel production by different routes in top 10 production countries in 2019. Data source: World Steel Association [7].

\begin{tabular}{cccccccc}
\hline & \multicolumn{2}{c}{ BF/BOF } & \multicolumn{2}{c}{ Scrap/EAF } & \multicolumn{2}{c}{ Other } & Total \\
\hline & Mt & & Mt & & Mt & Mt \\
\hline World & 1341 & $72 \%$ & 523 & $28 \%$ & 10 & $0.5 \%$ & 1874 \\
China & 893 & $90 \%$ & 103 & $10 \%$ & - & - & 996 \\
India & 49 & $44 \%$ & 63 & $56 \%$ & - & - & 112 \\
Japan & 75 & $76 \%$ & 24 & $24 \%$ & - & - & 99 \\
United States & 27 & $30 \%$ & 61 & $70 \%$ & - & - & 88 \\
Russia & 46 & $64 \%$ & 24 & $34 \%$ & 2 & $2 \%$ & 72 \\
South Korea & 49 & $68 \%$ & 23 & $32 \%$ & - & - & 72 \\
Germany & 28 & $70 \%$ & 12 & $30 \%$ & - & - & 40 \\
Turkey & 11 & $32 \%$ & 23 & $68 \%$ & - & - & 34 \\
Brazil & 25 & $76 \%$ & 7 & $22 \%$ & 0.5 & $2 \%$ & 33 \\
Iran & 3 & $10 \%$ & 23 & $90 \%$ & - & - & 26 \\
\hline
\end{tabular}

Crude steel is first processed by continuous casting where molten metals are continuously poured into a long mold, cooled down as they pass the long mold, and are then cut down to the desired size. After the continuous casting process, the hot rolling process is directly used to shape the metal into the desired steel product.

\section{The Low-Carbon Development of the ISI around the World}

This section first provided an overview of the world's ISI, and then described the low-carbon technology roadmap of the whole ISI of the world, including the current status, future vision, and key actions. 


\subsection{The Whole World}

\subsubsection{Overview of the World ISI}

In 1856, modern large-scale steelmaking was developed with the invention of the Bessemer process. Since this development, iron and steel have been the foundation material of economic development and supports sustainable economic development around the world, as shown in Figure 4.

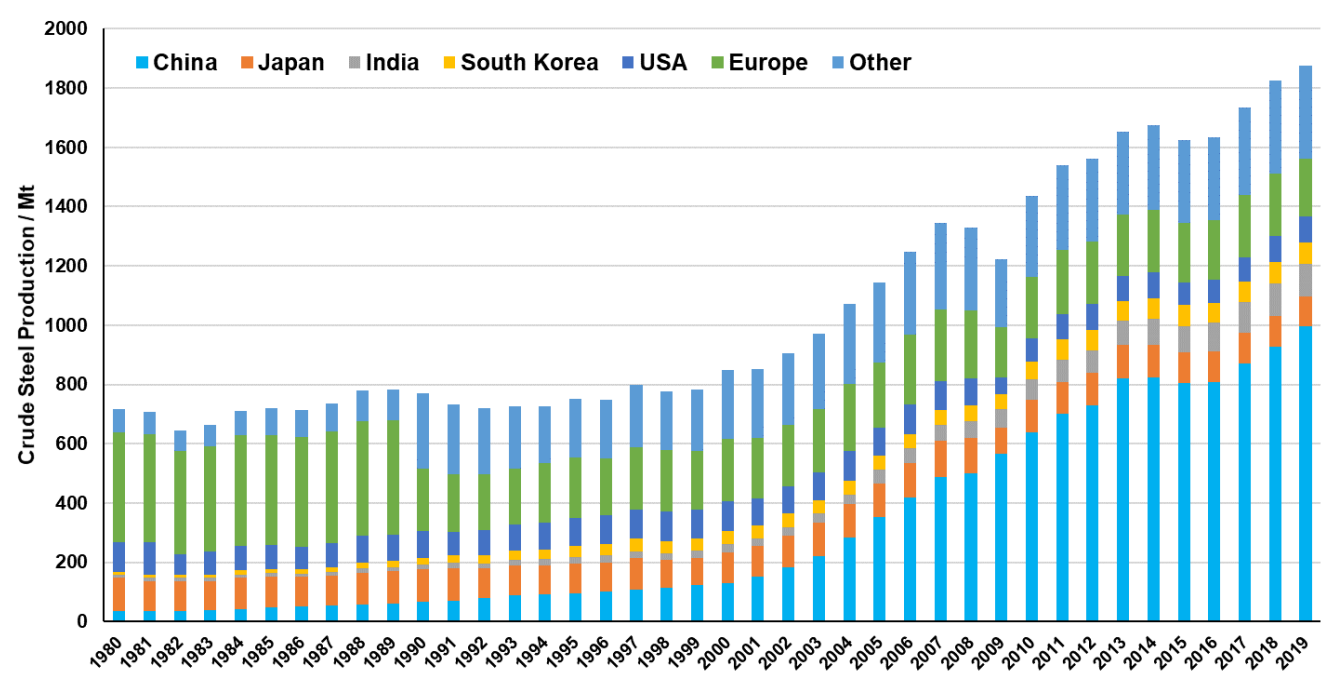

Figure 4. The global production of crude steel from 1980 to 2019. Data source: World Steel Association [34].

From the 1950s, the world ISI was under the first period of rapid development. In this period, European countries, Japan, and North America, started infrastructure reconstructions and industrialization after the World War II, which led to the increasing demand for iron and steel [10]. On the other hand, the production technologies of the ISI were rapidly innovated, such as the widespread promotion of the Basic Oxygen Furnace $(\mathrm{BOF})$ and the electric arc furnace $(\mathrm{EAF})$, resulting in the growing production of crude steel. In 1950, the global crude steel production was only $189 \mathrm{Mt}$, and it exceeded $500 \mathrm{Mt}$ in 1968, $600 \mathrm{Mt}$ in 1972, and $700 \mathrm{Mt}$ in 1974, respectively.

From the 1980s, the world ISI entered a period of stagnation. At that time, the ISI suffered from the global crisis and the energy supply crisis, causing the crude steel production to remain relatively constant at around $700 \mathrm{Mt}$.

After entering the 21st century, the world ISI has ushered into the second period of rapid development, and it is continuing. The rapid development during this period mainly resulted from the infrastructure construction and industrialization process of emerging economies, such as China and India. Especially, China's ISI has experienced very rapid development. The crude steel production of China exceeded $100 \mathrm{Mt}$ in 1996, making it the world largest steel producer, then in 2012 it exceeded half of the world's total production. In 2019, the crude steel production of China was $996 \mathrm{Mt}$ and 53\% of the global production share [7].

\subsubsection{Low-Carbon Technology Roadmap for the Whole World}

The Paris Agreement announced the global climate goal to limit global warming to well below $2{ }^{\circ} \mathrm{C}$, preferably to $1.5^{\circ} \mathrm{C}$, compared to pre-industrial levels [1]. As a typical "hard to abate sector", the decarbonization of the ISI is necessary but difficult, emitting 2.6 billion tons of direct $\mathrm{CO}_{2}$ emissions and representing $7 \%$ of global total emissions [5]. Encouragingly, $75 \%$ of 2021 global steelmaking capacity is in countries with net-zero targets for 2050 or 2060 [4], for example, the net-zero 2050 of the EU [35], South Korea [36] and Japan [37], the 2060 carbon neutrality of China [3]. 
The iron and steel technology roadmap, proposed by the International Energy Agency (IEA) [5] and revised by the World Steel Association (WSA) [4], urged the three-step approach for world steel's carbon reduction. Step 1 is to improve the energy performance of existing equipment including improvements in operational efficiency and implementing best available technologies, contributing around $20 \%$ of $\mathrm{CO}_{2}$ emissions savings in the Sustainable Development Scenario of IEA. Step 2 is to promote more efficient use of steel with the material efficiency measures along supply chains, for example, improving manufacturing yields and extending building lifetime, where the material efficiency strategies could contribute $40 \%$ of emission reduction. Step 3 is to develop breakthrough steelmaking processes, such as hydrogen, CCUS, bioenergy and direct electrification, accounting for around 39\% reduction. According to IEA's estimate, if these measures mentioned above are fully deployed, the $\mathrm{CO}_{2}$ emission intensity of steel may be reduced by more than $50 \%$, from $1.4 \mathrm{t} \mathrm{CO}_{2} / \mathrm{tcs}$ of today's level to $0.6 \mathrm{t} \mathrm{CO}_{2} / \mathrm{tcs}$ by 2050 . However, if targeted measures are not taken, the $\mathrm{CO}_{2}$ emissions would continue to rise to $2.7 \mathrm{Gt} \mathrm{CO}_{2}$ by 2050 , which is $7 \%$ higher than today [5].

To realize the sustainable transition for the ISI, governments are supposed to play a central role. IEA recommended the following policies for those seeking to effect change and accelerate the transition [5]: (1) Establishing a long-term and more ambitious $\mathrm{CO}_{2}$ emission reduction target; (2) managing existing assets and near-term investment; (3) increasing international cooperation and ensuring a level global playing field; (4) supporting the R\&D and demonstration of near-zero emission technologies. IEA believes that 2030 is a critical window to accelerate the transition, and three short-term priorities should be paid into the technical performance and material efficiency, the existing assets and new infrastructure, and the R\&D and demonstration of near-zero emission technologies.

\subsection{Main Steel Production Countries}

This section reviewed the low-carbon technology roadmap of the ISI around the main steel production countries of the world, including the current status, future vision, and key actions. Concerning the crude steel production and the geographical location, the countries of India, Japan, the United States, South Korea, and Germany were further reviewed one by one in the following sections.

\subsubsection{India}

As the world's third-largest carbon emitter, India has committed to the Paris Agreement to reduce its carbon emissions by 33-35\% from its 2005 level by 2030, but it has not announced its carbon-neutral target yet. The ISI is the biggest carbon emitter among India's industries, representing approximately $10 \%$ of total $\mathrm{CO}_{2}$ emissions [38], which will heavily affect India's push to cut emissions. However, the ISI in India is faced with a paradox. By 2050, India will be one of the few countries with growing steel demand as the economy grows, even under the pressure of global carbon neutrality [5]. The emissions of the Indian ISI were projected to more than quadruples in the next three decades, reaching $837 \mathrm{Mt}$, estimated from the Energy and Resources Institute in India [38].

Despite that India's pathway towards zero-carbon steel is "all or nothing", a feasible and step-wise pathway is still envisaged for Indian ISI, as outlined in the following key pillar [38]: (1) Improving energy efficiency by adopting best available energy efficiency technologies; (2) promoting resource efficiency and encouraging greater levels of material circularity; (3) implementing the promising transition options, such as the smelting reduction and CCUS, and switching to the hydrogen route steel production; and (4) promoting international collaboration and technology diffusion.

The good news is, some leading steel enterprises in India have stepped forward in lowcarbon steel development. ArcelorMittal, the largest steel producer in India and the second around the world, announced the launch of its first three XCarb ${ }^{\mathrm{TM}}$ initiatives, to support the company's journey to deliver on the commitment of reducing emissions by $30 \%$ by 2030 and achieving carbon neutrality by 2050. ArcelorMittal expected to realize the carbon-neutral 
steel by the flagship "Smart Carbon" projects, including Torero (transforming biomass into bio-coal to replace coal use in the BF) and Carbalyst (capturing carbon-rich BF waste gas and converting it into bio-ethanol), and the innovative DRI route [39]. Tata Steel, the second-largest steel producer in India, is also turning to a low-carbon steel production system and is committed to hydrogen-based steelmaking, carbon capture and utilization, and innovative smelting technologies [40]. The JSW steel, a private steel producer in India, has set a 2030 carbon emission target to cut 42\% carbon emission from 2005 level by 2030, exceeding India's NDC target of 33-35\% reduction [41].

It is worth mentioning that, India has paid much attention to the hydrogen-based steelmaking route, hoping to eliminate the $\mathrm{CO}_{2}$ emission of the ISI. It is estimated that, if hydrogen for steelmaking is generated from carbon-free electricity, total emissions of the Indian ISI can be reduced by $94 \%$ [38]. The government of India has announced the National Hydrogen Energy Mission, aiming to support a broad R\&D and demonstration project in hydrogen production from renewable energy sources, meaning the country could generate the world's cheapest hydrogen by 2050 using ultra-cheap renewable power [42].

\subsubsection{Japan}

The Government of Japan has declared the net-zero target by 2050 in October 2020, and then updated the 2030 GHG reduction target at 46\% from its 2013 level in April 2021 [37]. Given that the ISI emits $15 \%$ of all $\mathrm{CO}_{2}$ emissions in Japan and is the largest emitter among manufacturing industries [43], it is of significance for the Japanese ISI to support Japan's ambitious policy of achieving carbon neutrality by 2050. To contribute to the Japanese government policy, the Japan Iron and Steel Federation (JISF) announced the realization of zero-carbon steel by 2050 [44], while the previous target was set by 2100 before the government's carbon neutrality announcement. The Nippon Steel Corporation, the largest steel producer in Japan, declared to reduce $30 \%$ or more $\mathrm{CO}_{2}$ emissions from the 2013 level by 2030 and strive to achieve zero-carbon steel by 2050 [45]. The JEF Group, another enterprise engaged in iron and steel manufacturing in Japan, intended to reduce $\mathrm{CO}_{2}$ emissions by $20 \%$ or more from the 2013 level by 2030 and to be carbon neutral after 2050 [46].

The Japanese ISI will make a concerted effort to explore multiple pathways to the zero-carbon steel by employing every possible means, including the promotion of the drastic $\mathrm{CO}_{2}$ reduction in the existing blast furnace through the COURSE50 project and Ferro coke technologies plus CCUS, the development of super innovative technologies such as hydro-based iron-making, the expanded use of scrap, the recovery of low- to medium-temperature waste heat, and the use of biomass [44]. Besides, actions taken by the enterprises include the application of AI and data science technologies [46] and the promotion of lower-carbon power [45].

The COURSE50 project, abbreviated from the $\mathrm{CO}_{2}$ Ultimate Reduction System for Cool Earth 50, is given much attention for the realization of zero-carbon steel in Japan. The Course 50 project is funded by the New Energy and Industrial Technology Department Organization (NEDO) in 2008 and taken as a part of the grand hydrogen strategy in Japan [47]. The COURSE50 project aims to reduce $\mathrm{CO}_{2}$ emissions from the blast furnace by the combination of the hydrogen reduction technology and the separation and recovery technology for $\mathrm{CO}_{2}$ generated from the blast furnace [48]. The development of the COURSE50 project and the carbon-neutral potential are illustrated in Figure 5.

\subsubsection{The United States}

President Biden of the United States announced a new target in April 2021, aiming at a 50-52\% reduction from 2005 level in economy-wide net GHG pollution in 2030, as the product of the previous fulfilment to rejoin the Paris Agreement and the promise of reaching net-zero emissions economy-wide by no later than 2050 [49]. Biden's climate plan has put the infrastructure construction at its heart, which finally put steel into a central stage, responsible for $100 \mathrm{Mt}$ and approximately $1.5 \%$ of the total emissions [50]. One 
significant advantage of the US steel industry is its leadership in the recycling of scrap steel, accounting for about 70 percent of the raw metal input into steel production in the US, as listed in Table 1.

\section{Conventional BF}

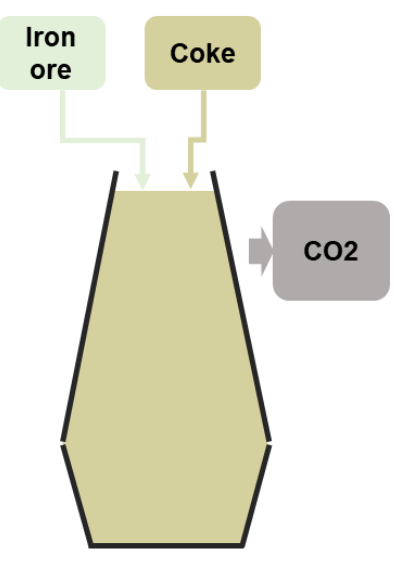

\section{COURSE50 BF}

\section{By-product hydrogen injection}

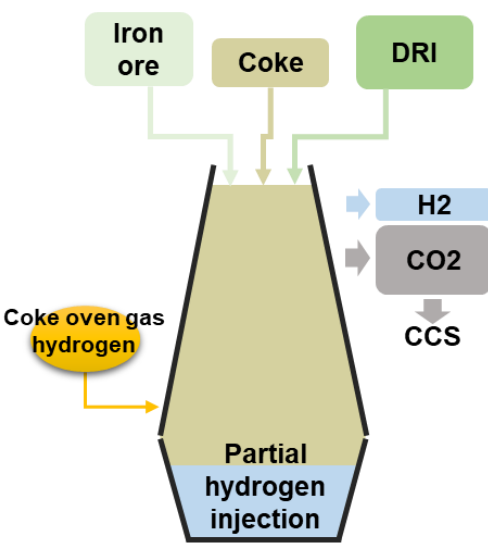

$30 \%$ CO2 reduction: $10 \%$ hydrogen $\& 20 \%$-CCS

\section{SUper COURSE50 BF}

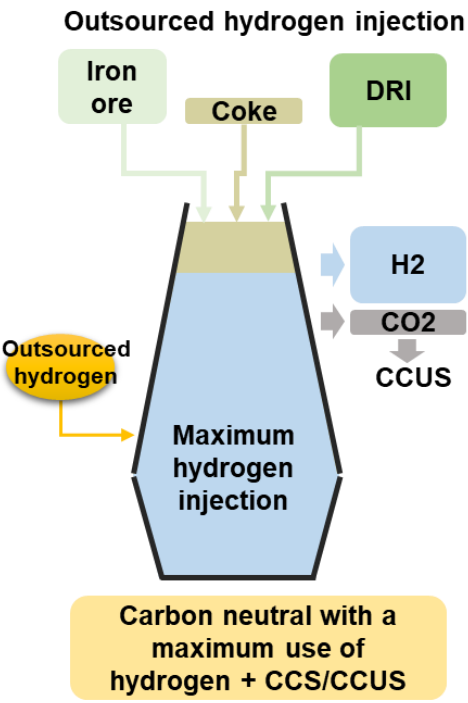

Figure 5. The development of the COURSE50 project in Japan.

Thus far, limited details could be found related to the carbon neutrality of the steel industry in the US. The White House stated that the implementation of green hydrogen to produce steel is the key to achieving its 2030 goals. The Nucor Corporation, the largest steel producer in the United States, has announced its GHG reduction target strategy in July of 2021 to reduce 35\% the Scope 1 and Scope 2 GHG intensity in its steel mills by 2030 compared to the 2015 baseline, and take the Nucor's steel mill $\mathrm{CO}_{2}$ emissions down to $77 \%$ less than today's global average [51]. It is said that the GHG emission intensity is currently at just $0.47 \mathrm{tCO}_{2} / \mathrm{tcs}$, "already among the leading steel companies" in its existing carbon footprint, and by 2030 it will be $0.38 \mathrm{tCO}_{2} / \mathrm{tcs}$. To ensure the attainment of the reduction target, approaches include promoting the use of renewable energy, implementing new energy efficiency projects, pursuing carbon capture and storage, investing in new recycled steel facilities, evaluating the long-term transformation technology including the use of renewable biocarbon, nuclear power, and green hydrogen. The United States Steel Corporation, a leading steel producer located at Pittsburgh in the US, is working towards the $20 \%$ reduction in GHG emission intensity (Scope 1 and Scope 2) by 2030, against the 2018 baseline, and committing to an even more aggressive goal to achieve net-zero emissions by 2050 [52]. The U.S. Steel will leverage its growing fleet of electric arc furnaces together with other technologies such as the direct reduced iron (DRI), carbon capture, sequestration and utilization, and carbon-free energy source.

\subsubsection{South Korea}

The government of South Korea released its 2050 carbon-neutral strategy in December 2020, stating Korea's NDC target of cutting GHG emission by 24.4\% by 2030 below 2017 level with the emission of 536 million $\mathrm{tCO}_{2}$-eq, and the vision of carbon neutrality by 2050 [36]. The ISI is a key sector in South Korea, which provides a basis for the developed manufacturing industry such as the automobile and the shipbuilding industry while representing $20 \%$ of the total emissions [53]. The ISI is expected to produce "Green Steel" by 2050. The POSCO Steel Corporation, the largest steel producer in South Korea, pledges to reduce the $\mathrm{CO}_{2}$ emission by $20 \%$ in the near-term by $2030,50 \%$ in the mid-term by 2040 , 
and the long-term carbon neutrality by 2050 from the average emission of $78.8 \mathrm{Mt}$ between 2017 to 2019 [54].

The low-carbon transition of the ISI of South Korea mainly focus on the following aspects, as stated by the government of South Korea [36]: (1) Applying new, future technologies, such as hydrogen-base direct reduction steelmaking and CCUS technology; (2) improving energy efficiency, including enhancing technical levels and promoting smart factories using Industry 4.0 technologies; (3) bring forward circular economy by reusing more scrap steels; and (4) increasing use of low-carbon fuels, mainly replacing fossil fuels with renewables and expanding the electrification.

To ensure the attainment of green steel by 2050, policies are supposed to address: (1) Creating a sustainable industry environment with the low-carbon transition and digital transformation. (2) Boosting investing in technology innovation along with the joint action by the Government and business, and building up an institutional framework and infrastructure in advance to ensure the timely deployment of developed technologies. (3) Increasing support for the energy efficiency improvement, such as the Emission Trading Scheme (ETS) in parallel with the voluntary reduction target, and tighten the energy efficiency standards of technical equipment.

The South Korea government is actively developing hydrogen-based steelmaking as the national core technology for the low-carbon transition of ISI [55]. If hydrogen could be used to reduce iron instead of cokes that inevitably emit $\mathrm{CO}_{2}$ in the blast furnace process, it could dramatically reduce GHG emission. In fact, the government and the business company have been collaborating to develop the hydrogen-based reduction steelmaking technology since 2017. It is considered as two key technologies of "the hydrogen production from the blast furnace by-product gas" and "the hydrogen-based direct reduction coupled with electric arc furnace (hydrogen-based DRI/EAF)". The plan of the hydrogen development in South Korea is to carry out the laboratory research from 2017 to 2020, then the pilot project before 2024, and finally preliminary commercial application between 2024 to 2030 .

\subsubsection{Germany}

The Germany government just passed a new federal Climate Action Law in June 2021, pulling forward the carbon neutrality target by five years to 2045, tightening the $2030 \mathrm{GHG}$ reduction target from 55\% to 65\% compared to 1990 level, and setting a new interim $88 \%$ reduction target for 2040 [56]. The ISI in Germany is a key sector for the attainment of the climate goal, with 58.8 million tonnes of $\mathrm{CO}_{2}$ emissions in 2018, responsible for one-third of industrial emissions and 10\% of total emissions [57]. The ISI in Germany is committed to a strong, internationally competitive and climate-neutral steel industry by 2050, definitely a carbon-neutral steel industry and preferably carbon-free steel industry, as declared by the federal government of Germany [57].

The government of Germany is working to introducing low-carbon, carbon-neutral and preferably carbon-free technologies in the ISI in Germany [57]. For example, using hydrogen replacing coke to reduce iron ore can offer great potential for the ISI in Germany and Europe (carbon direct avoidance, CDA). Additionally, carbon can be further used in the industrial value network (carbon capture and utilization, CCU). Besides, carbon capture and storage (CCS) is supposed to be a possible option for unavoidable emissions. In addition, the scrap-based steel production coupled with the electric arc furnace (Scrap/EAF) is an effective action in the short term. The Scarp/EAF route has offered $30 \%$ crude steel production in Germany, as listed in Table 1, whose share can be further increased, but will be limited by the availability of scrap steel.

The government of Germany designed an overarching policy framework, named the "Steel Action Concept", to support the carbon-neutral steel industry [57]. First, the instruments safeguard the international competitiveness of the steel sector throughout the transformation period, including creating a fair playing field for the steel market under the international rules and the trade negotiation, promoting the work of the Global Forum, 
and expanding and strictly applying trade-defense instruments. Second, this framework addresses how to prevent carbon leakage to countries with less stringent standards, along with continuing free allocation of emission allowance within the ETS (Emissions Trading System) in Europe and the compensation of electricity price, and assessing the role of the border adjustment tax against carbon leakage. Third, the government is promoting substantial investments to develop these innovative technologies in a commercially viable and affordable manner, as well as setting incentives and making regulations for low-carbon technologies and products, such as implementing carbon contracts to incentivize companies to invest in and operate low-carbon technologies.

The hydrogen in the steel industry plays an important role in the National Hydrogen Strategy of Germany [58]. The Federal Government believes that the hydrogen produced based on renewable energies, named green hydrogen, can offer opportunities for climate actions in the energy-intensive industries in which there are no technological alternatives or more efficient solutions for decarbonization, especially the steel industry [58]. Hydrogen is already being used in steel production in Germany, for example in the ThyssenKrupp AG, one of leading Europe's leading steel groups [59]. Additionally, the steel industry can bring huge demand for the utilization of green hydrogen, driving the expansion of the hydrogen market in Germany and the establishment of hydrogen infrastructure. To this end, the German federal government funds a wide range of programs, research and projects, seeks to promote the cost reduction of green hydrogen, the roll-out of the hydrogen market, and the establishment of the industrial chains.

\subsubsection{Summary}

In conclusion, for the attainment of the carbon neutrality commitment, the main steel-producing countries around the world have developed different specific technology roadmaps for the low-carbon development of the ISI, as listed in Table 2. There are multiple technology pathway combinations, and there is no single answer. Additionally, most of these existing technologies still face some unexpected challenges, particularly regarding the costs and public acceptance. Most countries place high hopes on disruptive innovative technologies, especially hydrogen reduced steelmaking. However, there are many problems to be solved by hydrogen-based steelmaking, such as technological innovation, large-scale demonstration, and some unknown issues. In summary, the low-carbon development of the ISI is a challenging task for almost all the countries around the world. 
Table 2. The low-carbon technology roadmap for the iron and steel industry around the world.

\begin{tabular}{|c|c|c|c|c|c|c|}
\hline & \multirow{2}{*}{ Release Authority } & \multirow{2}{*}{ Status } & \multirow{2}{*}{ Vision } & \multicolumn{3}{|c|}{ Action } \\
\hline & & & & Supply & Demand & Policy \\
\hline World & $\begin{array}{l}\text { International Energy } \\
\text { Agency [5] }\end{array}$ & $\begin{array}{l}7 \% \text { of global total } \\
\text { emissions }\end{array}$ & $\begin{array}{l}\text { At least } 50 \% \text { direct intensity } \\
\text { reduction by } 2050\end{array}$ & $\begin{array}{ll}\text { - Improving energy technology } \\
\text { performance to existing } \\
\text { equipment (21\% potential) } \\
\text { Promoting breakthrough } \\
\text { steelmaking processes, hydrogen, } \\
\text { CCUS, bioenergy and direct } \\
\text { electrification (39\% potential) }\end{array}$ & $\begin{array}{l}\text { - Pursuing a suite of } \\
\text { material efficiency } \\
\text { measures along supply } \\
\text { chains ( } 40 \% \text { potential) }\end{array}$ & $\begin{array}{l}\text { (Governments will play a central role): } \\
\text { - } \quad \text { Establishing a long-term and more } \\
\text { ambitious } \mathrm{CO}_{2} \text { emission reduction target } \\
\text { - } \quad \text { Managing existing assets and near-term } \\
\text { - } \quad \text { Investment } \\
\text { Increasing international cooperation and } \\
\text { - } \quad \text { Supuring a level global playing field } \\
\text { near-zero emist R\&D and demonstration of } \\
\text { (Expected by TERI): }\end{array}$ \\
\hline India & $\begin{array}{l}\text { The Energy and Resources } \\
\text { Institute in India [38] }\end{array}$ & $\begin{array}{l}2 \% \text { of } \mathrm{GDP} ; \\
10 \% \text { of total } \mathrm{CO}_{2} \text { emissions }\end{array}$ & - & $\begin{array}{l}\text { - Improving energy efficiency } \\
\text { Implementing the promising } \\
\text { transition options, like the } \\
\text { smelting reduction, CCUS } \\
\text { Switching to the hydrogen route } \\
\text { steel production }\end{array}$ & $\begin{array}{l}\text { Promoting resource } \\
\text { efficiency and } \\
\text { encouraging greater } \\
\text { levels of material } \\
\text { circularity }\end{array}$ & $\begin{array}{l}\text { - Promoting international innovation, } \\
\text { technology learning and diffusion } \\
\text { Proactively gaining supports from } \\
\text { developed countries } \\
\text { Stimulating demand for low-carbon steel in } \\
\text { the whole society } \\
\text { (Expected by JISF): }\end{array}$ \\
\hline Japan & $\begin{array}{l}\text { Japan Iron and Steel } \\
\text { Federation [44] }\end{array}$ & $15 \%$ of total $\mathrm{CO}_{2}$ emissions & $\begin{array}{l}\text { Striving to realize zero-carbon } \\
\text { steel by } 2050\end{array}$ & $\begin{array}{l}\text { Promotion of COURSE50 project } \\
\text { and the ferro coke technologies } \\
\text { plus CCUS in the blast furnace } \\
\text { Development of super innovative } \\
\text { technologies such as hydro-based } \\
\text { iron-making } \\
\text { - Recovery of low- to } \\
\text { medium-temperature waste heat } \\
\text { - Use of biomass }\end{array}$ & - Expanded use of scrap & $\begin{array}{l}\text { - Strong and continuous support for the } \\
\text { technological development, including } \\
\text { finical supports and public understandings } \\
\text { Design and development of a promotion } \\
\text { system and institutional design to } \\
\text { encourage the spirit of challenges } \\
\text { Introducing appropriate carbon pricing } \\
\text { measures }\end{array}$ \\
\hline $\begin{array}{l}\text { The United } \\
\text { States }\end{array}$ & - & $\begin{array}{l}1.5 \% \text { of total } \mathrm{CO}_{2} \\
\text { emissions [50]; } \\
\text { High share of Scarp/EAF } \\
\text { route and relatively lower } \\
\text { emission intensity [7] }\end{array}$ & $\begin{array}{l}\text { - The Nucor } \\
\text { Corporation-35\% GHG } \\
\text { intensity reduction by } \\
2030 \text { [51] } \\
\text { The U.S. Steel-20\% GHG } \\
\text { intensity reduction by } \\
2030 \text { [52] }\end{array}$ & $\begin{array}{ll}\text { - } & \text { Implementing new energy } \\
\text { - } & \text { efficiency projects } \\
\text { Promoting use of renewable } \\
\text { energy } \\
\text { - } \quad \text { Leveraging the DRI/EAF route } \\
\text { Pursuing carbon capture, } \\
\text { sequestration and utilization } \\
\text { Evaluating the long-term } \\
\text { transformation technology like } \\
\text { green hydrogen and renewable } \\
\text { biocarbon }\end{array}$ & $\begin{array}{l}\text { - } \quad \text { Investing in new } \\
\text { recycled steel facilities }\end{array}$ & - \\
\hline
\end{tabular}


Table 2. Cont.

\begin{tabular}{|c|c|c|c|c|c|c|}
\hline & \multirow{2}{*}{ Release Authority } & \multirow{2}{*}{ Status } & \multirow{2}{*}{ Vision } & \multicolumn{3}{|c|}{ Action } \\
\hline & & & & Supply & Demand & Policy \\
\hline South Korea & $\begin{array}{l}\text { The Government of the } \\
\text { Republic of Korea [36] }\end{array}$ & $20 \%$ of total $\mathrm{CO}_{2}$ emissions & $\begin{array}{l}\text { NDC: Carbon neutrality by } \\
2050\end{array}$ & $\begin{array}{ll}\text { - } & \text { Applying new, future } \\
\text { technologies, like hydrogen and } \\
\text { CCUS } \\
\text { - } \quad \text { Improving energy efficiency } \\
\text { - } \quad \begin{array}{l}\text { Increasing the use of low-carbon } \\
\text { fuels }\end{array} \\
\text { - Reducing F-gas from industrial } \\
\text { processes }\end{array}$ & $\begin{array}{l}\text { - Bring forward circular } \\
\text { economy }\end{array}$ & $\begin{array}{ll}\text { - } & \text { Creating a sustainable industry } \\
\text { environment } \\
\text { - } \\
\text { Boosting investment in technology } \\
\text { innovation } \\
\text { Increasing support for energy efficiency } \\
\text { improvement }\end{array}$ \\
\hline Germany & $\begin{array}{l}\text { The Federal Government } \\
\text { [57] }\end{array}$ & $10 \%$ of total $\mathrm{CO}_{2}$ emissions & $\begin{array}{l}\text { A strong, internationally } \\
\text { competitive and } \\
\text { climate-neutral steel industry } \\
\text { by } 2050\end{array}$ & $\begin{array}{l}\text { - Using hydrogen replacing coke to } \\
\text { reduce iron ore (Great potential) } \\
\text { Making further use of carbon } \\
\text { within the industrial value } \\
\text { network } \\
\text { Applying the carbon capture and } \\
\text { storage for unavoidable emissions } \\
\text { - } \quad \text { Increasing the Scrap/EAF route } \\
\text { production (Limited potential) }\end{array}$ & - & $\begin{array}{l}\text { - Creating a level playing field for steel } \\
\text { market } \\
\text { Avoiding carbon leakage to countries with } \\
\text { less stringent standards } \\
\text { Promoting substantial investments in } \\
\text { innovative technologies }\end{array}$ \\
\hline
\end{tabular}




\section{The Low-Carbon Development of the ISI of China}

As the largest steel-producing country around the world, China faces great challenges for the low-carbon development in the ISI along with the developing economy. Given that China has not officially published its technology roadmap, this section comprehensively reviews the current status, goal, and especially evaluated the potential of key actions for the low-carbon development of China's ISI.

\subsection{Current Status of the ISI in China}

Steel has provided a good foundation for the developing economy in China, supporting urbanization, industrialization, and infrastructure construction. As shown in Figure 6, the increasing trend of China's crude steel production is almost in line with the GDP growth during 1978-2019.

In 1980, the construction of the "Hanyang Iron and Steel Plant" in Wuhan City of China opened the prelude to modern steel production in China, but it was limited by backward technologies and low outputs. Since the founding of New China in 1949, China's ISI has been initially rebuilt and developed, with the output from $0.16 \mathrm{Mt}$ in 1949 to $18 \mathrm{Mt}$ in 1970 [60]. Especially, since the implementation of China's reform and opening-up policy in 1978, China's ISI has developed rapidly and achieved amazing achievements, which can be divided into the following three phases, as shown in Figure 6.

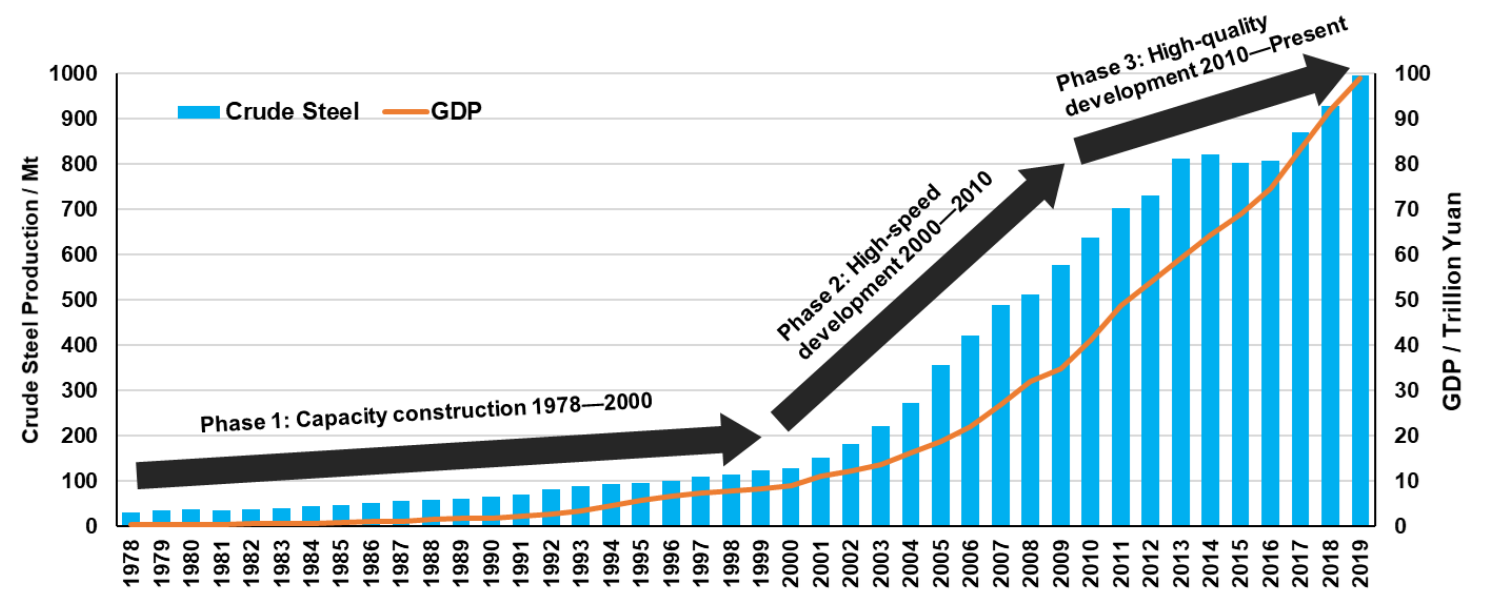

Figure 6. China's crude steel production and GDP during 1978-2019. Data source: China Steel Association [6] and National Bureau of Statistics of China [61].

Phase 1: Capacity construction during 1978-2000. During this period, China's ISI mainly focused on capacity construction and the industry layout. Under the implementation of the reform and opening-up policies, China has built a number of modern large-scale iron and steel enterprises with the world's advanced level, and carried out technological upgrading and transformation of old iron and steel enterprises. Besides, China has gradually established its market economic system and modern enterprise system, which injected a strong impetus into the development of ISI. In 1996, China's crude steel production exceeded $100 \mathrm{Mt}$ for the first time, reaching $101 \mathrm{Mt}$ and accounting for $13.5 \%$ of the world's total outputs, surpassing Japan and the United States to become the world's largest steel producer.

Phase 2: High-speed development during 2000-2010. During this period, China's ISI has achieved sustained and high-speed development along with fast economic development. With the acceleration of urbanization and the upgrading of consumption structure, the steel demand increased rapidly, and the ISI was vigorously developed in various places, resulting in a rapid increase in crude steel production. In 2005, China's crude steel production reached $360 \mathrm{Mt}$, with a record annual growth rate of $30.4 \%$, and became the first country around the world to exceed $300 \mathrm{Mt}$ of crude steel production. Subsequently, 
China's crude steel production continued to increase to $420 \mathrm{Mt}$ in 2006, $510 \mathrm{Mt}$ in 2008, and $640 \mathrm{Mt}$ in 2010.

Phase 3: High-quality development from 2010 to the present. From 2010 to the present, to control the excessive development of the ISI and the repeated construction of backward production capacity, China has intensified its macro-control over the ISI. Under the pressure of eliminating backward production capacity, environmental protection, and recent $\mathrm{CO}_{2}$ emission reduction, China's ISI is undergoing a transition towards a highefficient, clean, and low-carbon development model. Meanwhile, China's crude steel achieved a new high of $1053 \mathrm{Mt}$ and $56 \%$ of the global share in 2020 even among the COVID-19 pandemic [62].

With the rapid growth of crude steel production in China, the pressure on $\mathrm{CO}_{2}$ emission reduction of China's iron and steel is growing larger and larger. China's ISI emitted increasing $\mathrm{CO}_{2}$ from $444 \mathrm{Mt}$ in 2000 to $2456 \mathrm{Mt}$ in 2019, as shown in Figure 7. The combustion of fossil fuels, especially the use of coke, resulted in the majority of $\mathrm{CO}_{2}$ emissions. Moreover, great efforts have been made in energy conservation and emission reduction in China's ISI. The intensity of $\mathrm{CO}_{2}$ emissions has been declining year by year, from $3.2 \mathrm{tCO}_{2} /$ tce in 2000 to $1.6 \mathrm{tCO}_{2} /$ tce in 2019. However, China's $\mathrm{CO}_{2}$ emission intensity is still far behind the world advanced level, for example, $0.47 \mathrm{tCO}_{2} /$ tce in the US [51], which was mainly resulted from China's high proportion of energy-intensive BF/BOF steelmaking route and low process energy efficiency.

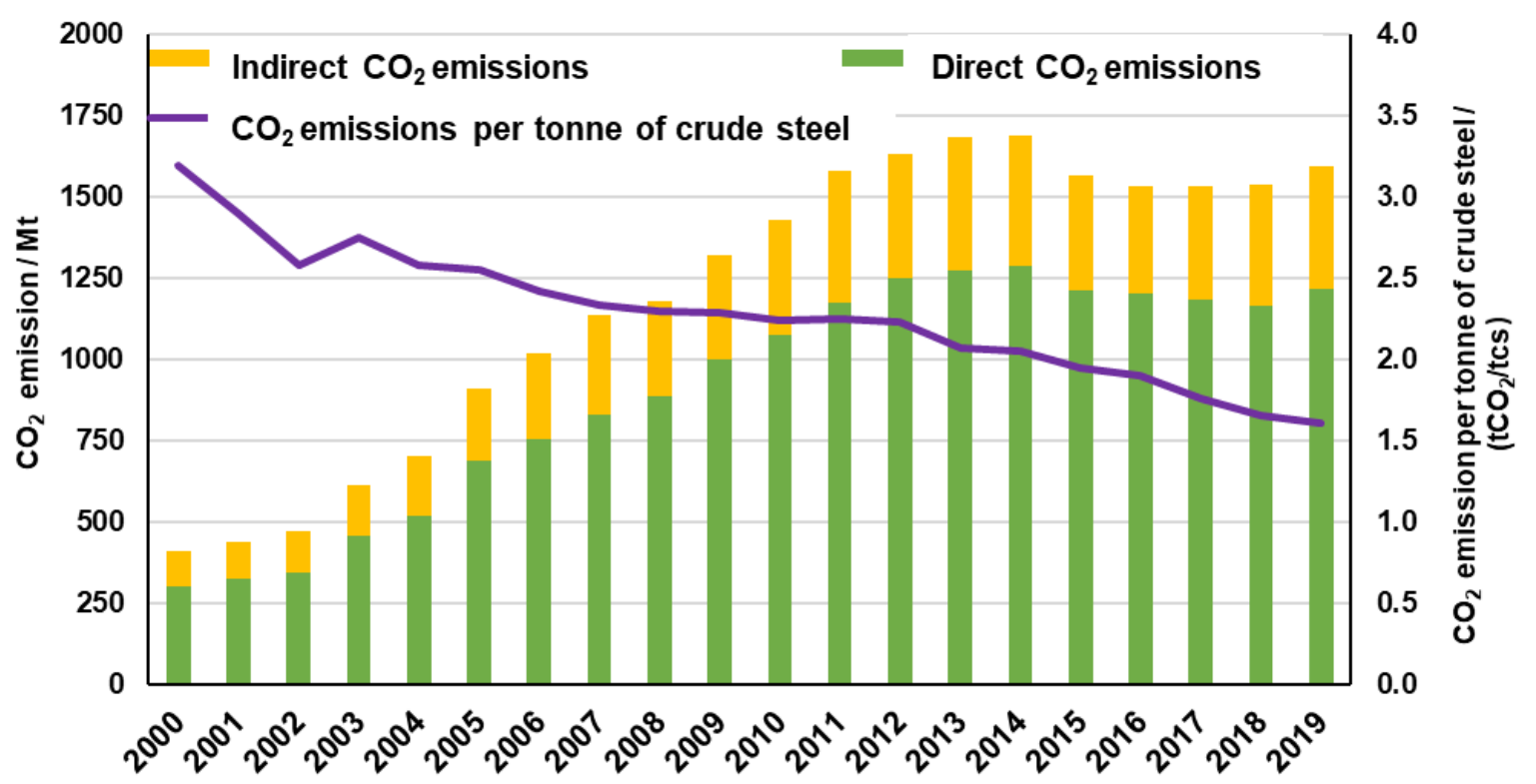

Figure 7. $\mathrm{CO}_{2}$ emissions of China's ISI during 2000-2019. Data source: China Energy Statistical Yearbook [63].

\subsection{The Goal for the Low-Carbon Development of the ISI in China}

The China's President, Xi Jinping, has announced the ambitious climate goal of China in September 2020 that: "China aims to have $\mathrm{CO}_{2}$ emission peak before 2030 and achieve carbon neutrality before 2060" [3]. Following this climate goal, the specific action plans for different sectors are formulating on the way.

While the official action plans for China's ISI have yet to be released, some organizations and enterprises have already stepped forward, as listed in Table 3. The China Baowu Group, the biggest iron and steel enterprise in China and becoming the largest global steel producer in 2020, has released its $\mathrm{CO}_{2}$ reduction declaration that: "The China Baowu Group aims to peak the $\mathrm{CO}_{2}$ emission in 2023, reduce the $\mathrm{CO}_{2}$ emission by $30 \%$ in 2035, and achieve carbon neutrality by 2050" [64]. The HBIS Group, the second-largest steel producer in China, announced its "Low carbon \& Green Development Action Plan" in March 2021, aiming to have an emission peak in 2022, more than $10 \%$ carbon reduction by 2025 and 
$30 \%$ reduction by 2030 compared to the peak level, and carbon neutrality by 2050 [65]. The China Metallurgical Industry Planning and Research Institute, a consulting institute focused on the ISI, initially set the target for China's ISI to achieve a carbon emission peak by 2025 , reduce $30 \%$ from the peak level by 2030 , and achieve decarbonization by 2060 [66].

Table 3. The goal set for the low-carbon development of the ISI in China.

\begin{tabular}{|c|c|c|}
\hline & Release Time & Goal \\
\hline China Baowu Group [64] & January 2021 & $\begin{array}{l}\text { Peaking the } \mathrm{CO}_{2} \text { emission in } 2023 \text {, reducing the } \\
\qquad \mathrm{CO}_{2} \text { emission by } 30 \% \\
\text { in 2035, and achieving carbon neutrality by } 2050\end{array}$ \\
\hline The HBIS Group [65] & March 2021 & $\begin{array}{l}\text { Carbon emission peak in } 2022, \text { more than } 10 \% \\
\text { carbon reduction by } 2025 \text { and } 30 \% \text { reduction by } \\
2030 \text { compared to the peak level, } \\
\text { and carbon neutrality by } 2050\end{array}$ \\
\hline $\begin{array}{l}\text { China Metallurgical Industry } \\
\text { Planning and Research } \\
\text { Institute [66] }\end{array}$ & March 2021 & $\begin{array}{l}\text { Achieving carbon emission peak by } 2025 \text {, reducing } \\
30 \% \text { from the peak level by 2030, and achieving } \\
\text { decarbonization by } 2060\end{array}$ \\
\hline
\end{tabular}

\subsection{Key Actions for the Low-Carbon Development of the ISI in China}

Concerning that there has not yet been a specific low-carbon action plan, this section reviewed these available key actions and evaluated their potential in detail for China's ISI.

\subsubsection{Improving Energy Efficiency}

In the short term, the energy efficiency improvement is considered as the most important action for the low-carbon development of the ISI in China. In the past decades, great efforts have been made in energy efficiency improvements and energy saving in China's ISI. As shown in Figure 8, the comparable energy consumption per ton of crude steel has declined from $784 \mathrm{kgce} / \mathrm{tce}$ in 2000 to $605 \mathrm{kgce} / \mathrm{tce}$ in 2019 [63]. However, it still lags behind the global advanced technological level, such as $576 \mathrm{kgce} / \mathrm{tce}$ in Germany [63].

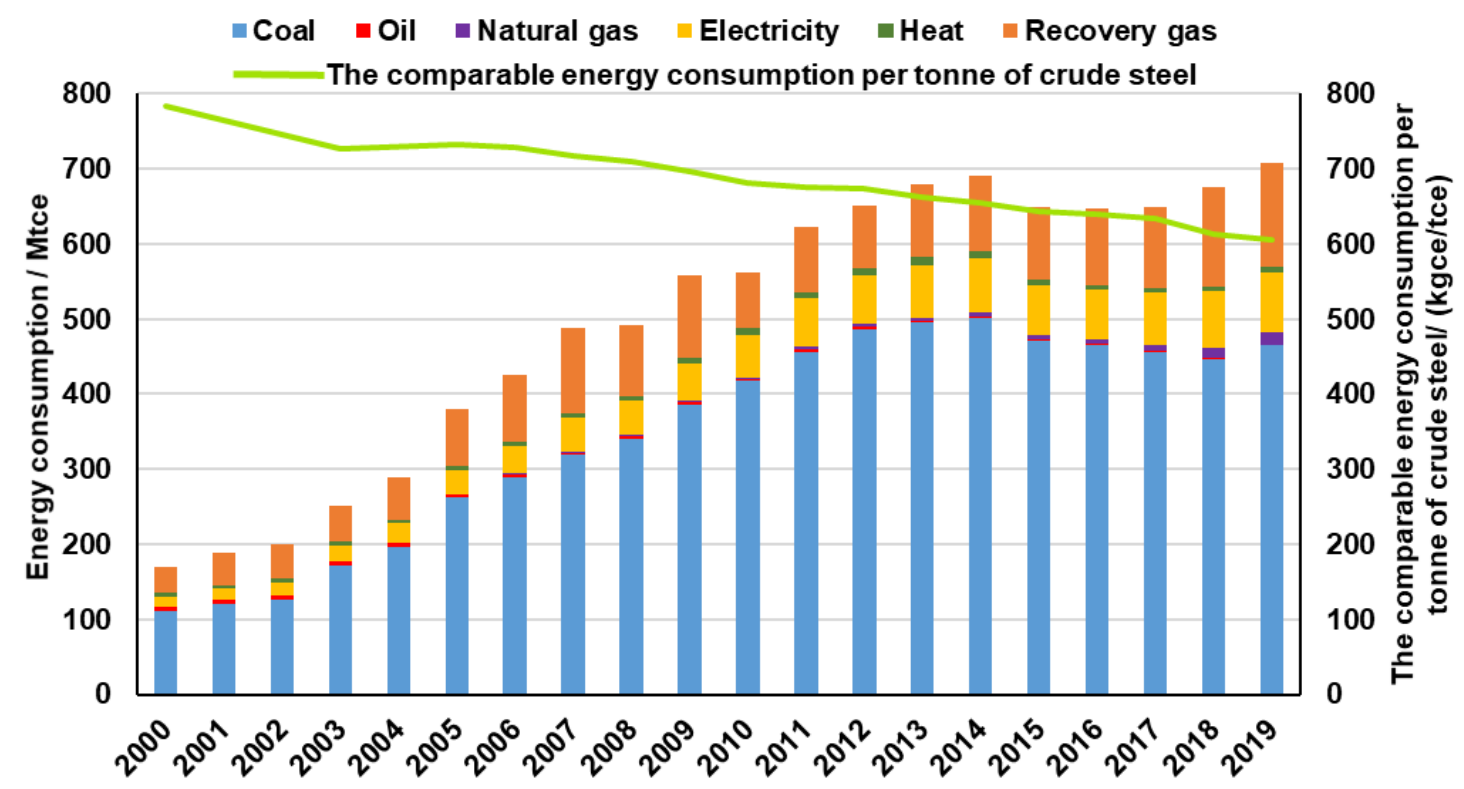

Figure 8. Energy consumption of China's ISI during 2000-2019. Data source: China Energy Statistical Yearbook 2020 [63].

Looking into the process energy intensity as listed in Table 4, they all showed a decreasing trend during 2010-2019, resulting from the progress of energy technology 
and energy management across the whole industry. Interestingly, there have been some fluctuations in energy efficiency levels in the past five years, which may be caused by the strict policy of production control in China. On the other hand, there is still a gap between China's energy efficiency level and the world's best practice, for example, $387.4 \mathrm{kgce} / \mathrm{t}$ of China's BF ironmaking process compared to $341 \mathrm{kgce} / \mathrm{t}$ of world best practice [67]. Additionally, China still has some backward production capacity, whose efficiency levels are much lower than the average value in Table 4. In a word, there is still considerable carbon reduction potential for energy efficiency improvement in China's ISI.

Table 4. Process energy intensity of China's ISI during 2010-2019. Data source: China Iron and Steel Association [6].

\begin{tabular}{|c|c|c|c|c|c|c|}
\hline Unit: kgce/t & Coking & Sintering & $\begin{array}{c}\mathrm{BF} \\
\text { Ironmaking }\end{array}$ & $\begin{array}{c}\text { BOF } \\
\text { Steelmaking }\end{array}$ & $\begin{array}{c}\text { EAF } \\
\text { Steelmaking }\end{array}$ & Steel Rolling \\
\hline 2010 & 105.9 & 52.7 & 407.8 & -0.2 & 74.0 & 55.5 \\
\hline 2011 & 107.5 & 51.9 & 406.5 & -2.6 & 70.4 & 52.6 \\
\hline 2012 & 105.1 & 50.5 & 402.5 & -6.2 & 66.9 & 53.0 \\
\hline 2013 & 100.0 & 49.2 & 398.1 & -7.2 & 62.2 & 51.9 \\
\hline 2014 & 97.7 & 48.5 & 393.0 & -9.9 & 58.5 & 59.1 \\
\hline 2015 & 96.9 & 49.4 & 390.9 & -11.4 & 59.3 & 59.9 \\
\hline 2016 & 100.1 & 49.9 & 396.6 & -14.0 & 58.5 & 56.7 \\
\hline 2017 & 99.7 & 48.5 & 390.8 & -13.9 & 58.1 & 56.9 \\
\hline 2018 & 104.9 & 48.6 & 392.1 & -13.4 & 55.7 & 54.3 \\
\hline 2019 & 105.8 & 48.2 & 387.4 & -15.0 & 57.2 & 51.9 \\
\hline $\begin{array}{c}\text { Best practice } \\
{[66]}\end{array}$ & 62 & 23 & 341 & -22 & 23 & 27 \\
\hline
\end{tabular}

The energy efficiency improvement of ISI has been analyzed in most previous studies $[9,10,23,68]$. To sum it up, three key ways can be identified for the energy efficiency improvement in China's ISI:

- Switching to more efficient processing equipment, such as improving the blast furnace efficiency and phasing out backward production equipment.

- Increased recovery of by-products and waste, such as power generation from recovered blast furnace gas (BFG) and preheating from process waste heat.

- Adopting more efficient methods for casting and rolling of final steel product, such as intelligent monitoring and controlling of the process.

Table 5 listed the technology selections for the energy efficiency improvement available for each process $[10,68,69]$. With the advocacy and support for energy efficiency improvement over the years, some energy-efficient technologies have achieved good technology maturity and market penetration, such as the coke dry quenching (CDQ) in the coking process. On the other hand, some emerging energy-efficient technologies with carbon reduction potential are at small-scale commercialization stage, still constrained by the high cost and needed to be further developed. 
Table 5. Technology selections for the energy efficiency improvements available in China's ISI. Data source: He and Wang [10], Zhang, et al., [68], and Li and Zhu [69].

\begin{tabular}{|c|c|c|c|c|c|}
\hline Process & Technology & $\begin{array}{l}\text { Energy Saving } \\
\text { Potential/(GJ/t) }\end{array}$ & $\begin{array}{l}\mathrm{CO}_{2} \text { Reduction } \\
\text { Potential/(kg/t) }\end{array}$ & $\begin{array}{c}\text { Annualized } \\
\text { Investment/(CNY/t) }\end{array}$ & $\begin{array}{c}\text { Current Market } \\
\text { Penetration } b\end{array}$ \\
\hline \multirow[t]{3}{*}{ Coking } & $\begin{array}{l}\text { Coke dry quenching } \\
\text { (CDQ) }\end{array}$ & 0.37 & 42.54 & 180 & $\bullet \bullet \bullet$ \\
\hline & $\begin{array}{c}\text { Coal moisture control } \\
\text { (CMC) }\end{array}$ & 0.06 & 1.47 & 160 & $\bullet$ \\
\hline & $\begin{array}{l}\text { Preheat of sinter } \\
\text { plant }\end{array}$ & 0.12 & 12.85 & 22 & $\bullet \bullet \bullet$ \\
\hline \multirow{3}{*}{ Sintering } & Use of waste fuels & 0.11 & 11.78 & 1 & $\bullet \bullet \bullet$ \\
\hline & $\begin{array}{l}\text { Low temperature } \\
\text { sintering }\end{array}$ & 0.35 & 3.15 & 2 & $\bullet$ \\
\hline & $\begin{array}{l}\text { Sintering waste heat } \\
\text { recovery }\end{array}$ & 0.35 & 14.77 & 33 & $\bullet$ \\
\hline \multirow[t]{5}{*}{ BF ironmaking } & $\begin{array}{c}\text { Recovery of BFG } \\
\text { High-efficient }\end{array}$ & 0.01 & 5.49 & 9 & $\bullet \bullet \bullet$ \\
\hline & $\begin{array}{l}\text { pulverized coal } \\
\text { injection }(130 \mathrm{~kg} / \mathrm{t}) \\
\text { Top pressure }\end{array}$ & 0.70 & 24.16 & 155 & $\bullet \bullet$ \\
\hline & $\begin{array}{l}\text { recovery turbines } \\
\text { (dry type) }\end{array}$ & 0.12 & 22.66 & 60 & $\bullet$ \\
\hline & $\begin{array}{l}\text { Double preheating } \\
\text { for hot stove }\end{array}$ & 0.25 & 1.30 & 16 & $\bullet$ \\
\hline & $\begin{array}{l}\text { Injection of Plastic } \\
\text { Waste }\end{array}$ & 0.10 & 11.78 & 10 & $\bullet$ \\
\hline \multirow[t]{3}{*}{ BOF steelmaking } & $\begin{array}{l}\text { BOF gas sensible heat } \\
\text { recovery } \\
\text { Converter Gas Dry } \\
\text { Dedusting }\end{array}$ & 0.12 & 19.28 & 167 & $\bullet$ \\
\hline & $\begin{array}{l}\text { Technology (wet type } \\
\text { transformed into dry } \\
\text { type) }\end{array}$ & 0.14 & 5.77 & 26 & $\bullet$ \\
\hline & $\begin{array}{l}\text { Increasing Thermal } \\
\text { Efficiency by re-using } \\
\text { BOF Exhaust Gas }\end{array}$ & 0.09 & 2.89 & 140 & $\bullet$ \\
\hline \multirow{2}{*}{ EAF steelmaking } & $\begin{array}{l}\text { optimization } \\
\text { techniques }\end{array}$ & 0.01 & 2.31 & 1 & $\bullet$ \\
\hline & $\begin{array}{l}\text { EAF gas waste heat } \\
\text { recovery }\end{array}$ & 0.06 & 77.10 & 38 & $\bullet$ \\
\hline \multirow[t]{2}{*}{ Steel casting } & $\begin{array}{l}\text { High-efficient } \\
\text { continuous casting }\end{array}$ & 0.39 & 27.49 & 400 & $\bullet \bullet$ \\
\hline & $\begin{array}{l}\text { Efficient ladle } \\
\text { preheating }\end{array}$ & 0.02 & 0.58 & 2 & $\bullet$ \\
\hline \multirow[t]{5}{*}{ Steel rolling } & $\begin{array}{l}\text { Hot rolling and hot } \\
\text { charging }\end{array}$ & 0.23 & 26.78 & 100 & $\bullet \bullet$ \\
\hline & $\begin{array}{l}\text { Process control in hot } \\
\text { strip mill } \\
\text { Automated }\end{array}$ & 0.28 & 20.49 & 20 & $\bullet \bullet \bullet$ \\
\hline & $\begin{array}{l}\text { monitoring and } \\
\text { targeting } \\
\text { system }\end{array}$ & 0.20 & 13.22 & 12 & $\bullet \bullet$ \\
\hline & Waste heat recovery & 0.03 & 3.21 & 24 & $\bullet \bullet$ \\
\hline & $\begin{array}{c}\text { Endless Strip } \\
\text { Production (ESP) }\end{array}$ & 0.28 & 6.99 & 182 & $\bullet$ \\
\hline \multirow{3}{*}{$\begin{array}{l}\text { Other } \\
\text { comprehensive } \\
\text { technologies }\end{array}$} & $\begin{array}{l}\text { Preventative } \\
\text { maintenance }\end{array}$ & 0.49 & 50.40 & 10 & $\bullet \bullet \bullet$ \\
\hline & $\begin{array}{l}\text { Combined heat and } \\
\text { power generation } \\
\text { technology }\end{array}$ & 0.38 & 70.19 & 60 & $\bullet \bullet$ \\
\hline & $\begin{array}{l}\text { Energy monitoring } \\
\text { and management } \\
\text { technology }\end{array}$ & 0.12 & 18.22 & 5 & $\bullet \bullet$ \\
\hline
\end{tabular}

Note: ${ }^{\text {a }}$ Data of the investment cost are estimated from He and Wang [10] and Li and Zhu [69]. It is note that these figures only represent current costs, which may decline in the future as market penetration increases and technology advances; ${ }^{\mathrm{b}} \bullet \bullet \bullet(70-100 \%) ; \bullet \bullet(40-70 \%)$; - $(0-40 \%)$.

\subsubsection{Shifting to Scrap/EAF Route}

The scrap steel/electric arc furnace route (Scrap/EAF route) is considered a promising steel production route with huge $\mathrm{CO}_{2}$ emission reduction potential. The $\mathrm{CO}_{2}$ emission intensity of the Scrap/EAF route is only about a quarter of that of the BF/BOF route, as electricity is used instead of coke [33]. Additionally, if low-carbon electricity can be used 
for the Scrap/EAF route, such as solar power and wind power, the $\mathrm{CO}_{2}$ emission intensity will be further reduced. The emission reduction effect of a high proportion of Scrap/EAF steelmaking route has been proven in the United States, with 70 percent of crude steel produced from the Scrap/EAF route [7] and $0.47 \mathrm{tCO}_{2} /$ tce [51], which is already lower than the IEA's global vision of $0.6 \mathrm{tCO}_{2} /$ tce in the 2050 Sustainable Development Scenario [5].

However, the proportion of China's crude steel production from the scarp/EAF steel is still at a low level and far behind the world advanced level. In the past two decades, the share of Scrap/EAF crude steel production has been in a downwards trend while the total crude steel production has been growing rapidly, only $10 \%$ crude steel producing from Scrap/EAF route in 2019, as shown in Figure 9. On the other hand, among countries of the world's top 20 steel producers, China's share of the Scrap/EAF route is below the world average level of $28 \%$ and $50 \%$ of the world except for China, and far behind the world's advanced level, such as $80 \%$ in Italy, as shown in Figure 10.

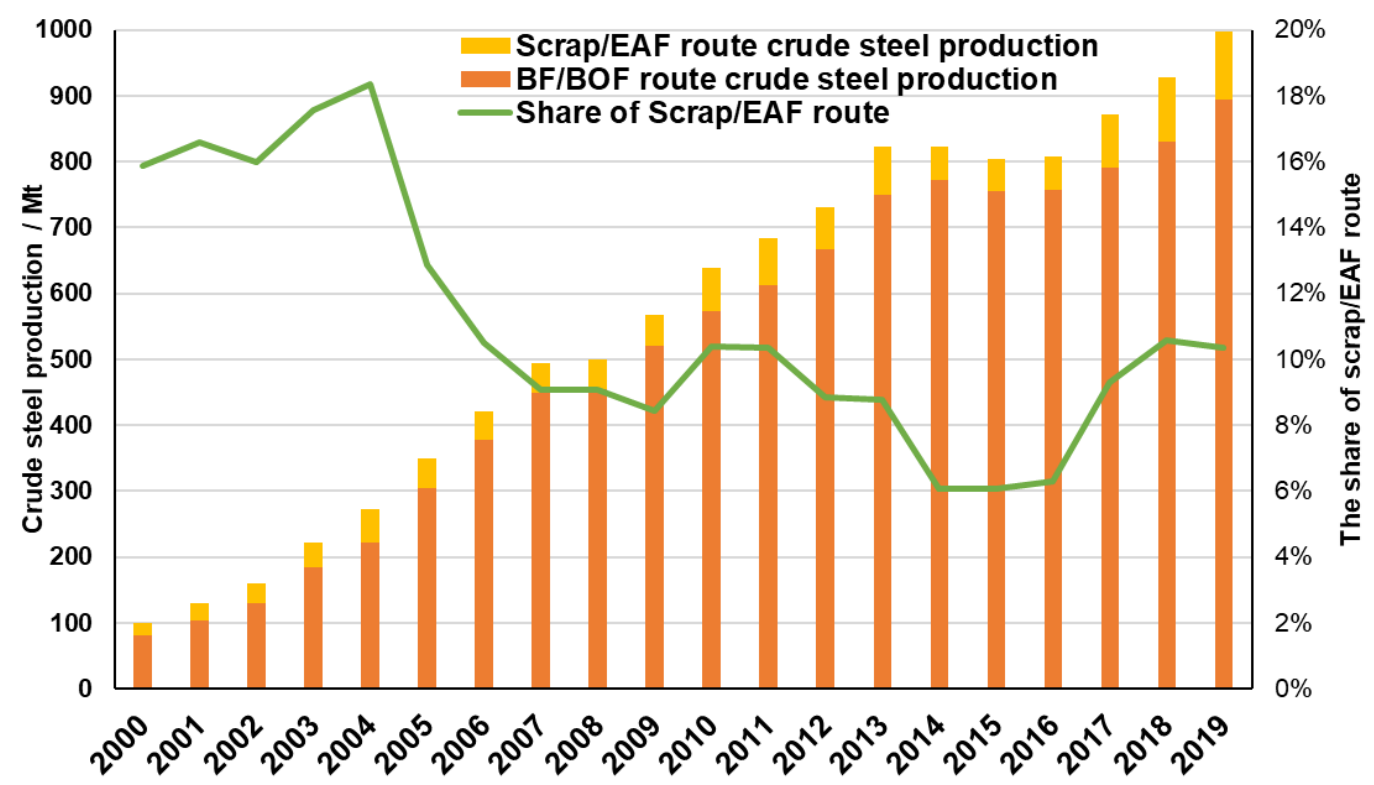

Figure 9. China's crude steel production from Scrap/EAF route during 2000-2019. Data source: World Steel Association [34].

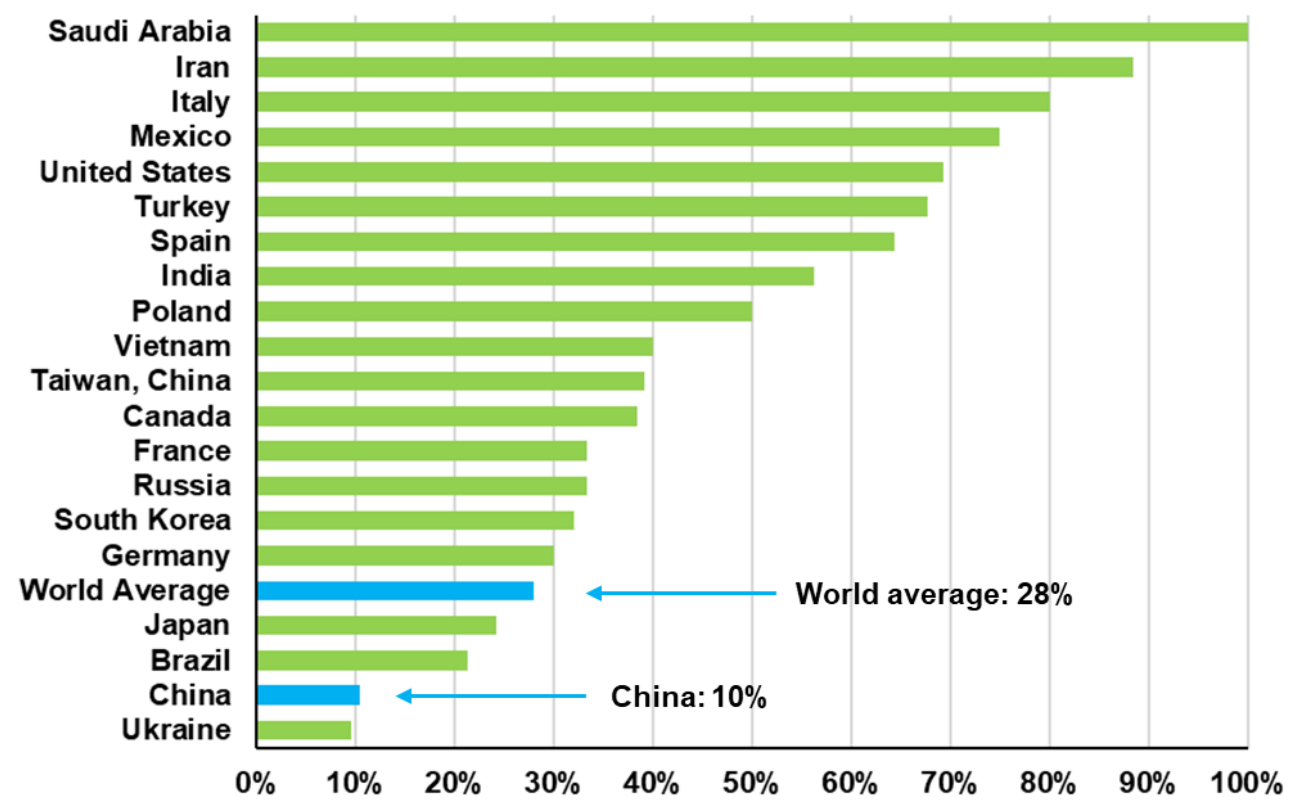

Figure 10. The share of Scrap/EAF route among top 20 steel-producing countries in 2019. Data source: World Steel Association [7]. 
The insufficient supply of scrap steel is the main reason why China has been in a low share of the Scrap/EAF route for such a long time. In general, scrap steel can be obtained from the following three ways $[33,70]$ :

- Home (or return) scrap. This scrap comes from waste steel generated in the steelmaking process including rolling, cutting, conditioning, and trimming.

- Societal scrap. This scrap includes prompt (or industrial) scrap from the downstream manufacturing process, and obsolete (or postconsumer) scrap recovered from end-oflife steel products, such as machines, buildings, and cars.

- Imported scrap. This scrap is imported from other countries.

The supply and the consumption of scrap steel in China during 2001-2019 are illustrated in Figure 11. Currently, the scrap steel supply in China is not enough to support such a big crude steel production, $240 \mathrm{Mt}$ scrap steel supply compared to $995 \mathrm{Mt}$ crude steel production. In China, scrap steels mainly come from societal scraps from steel manufacturing and end-of-life steel products. It is noteworthy that, during 2017-2018, the supply of societal scraps has grown wildly, mainly generated from the elimination of backward production and grey production in China [71]. In addition to the domestic scrap supply, China also imported scraps from other countries, such as Japan and the US [72]. Since China imported the first ship of scrap steel in 1985, China has always been the world's main scrap importer. In 2009, China imported 10.2 Mt of scrap steels, reaching the highest level in the past years [72]. However, with the increasing price of scrap steels, the imported scrap has decreased to $1.02 \mathrm{Mt}$ in 2018 , with less than $1 \%$ share.

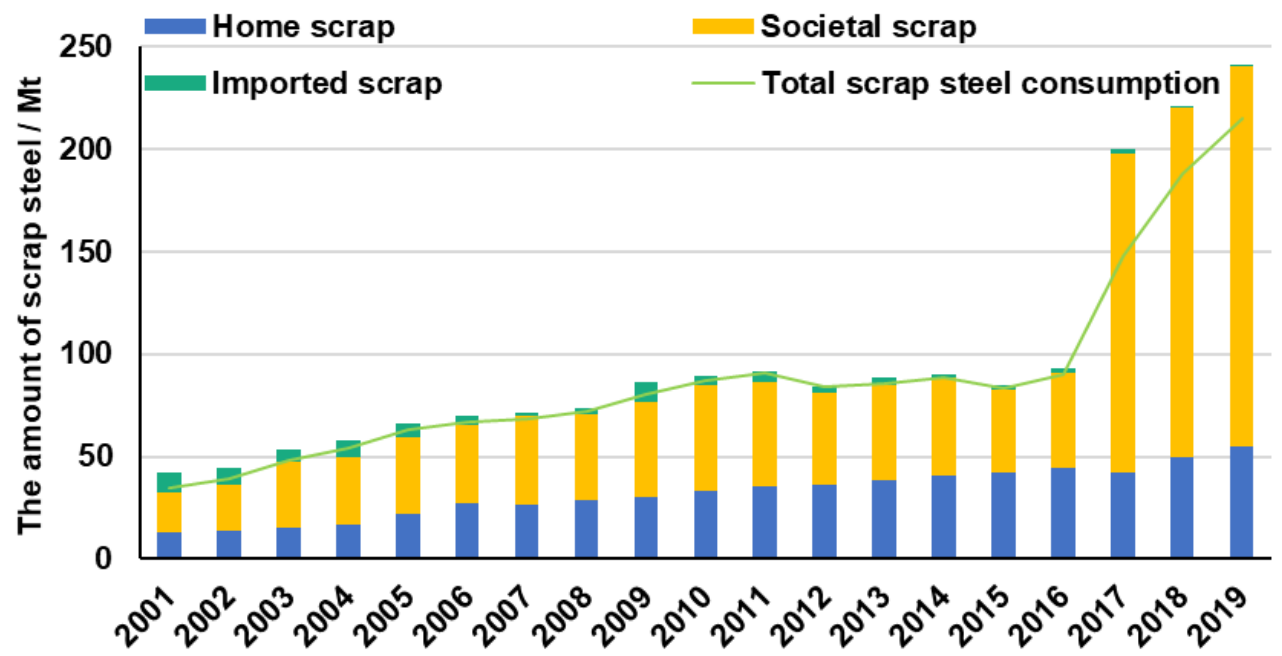

Figure 11. The supply and consumption of scrap steel in China during 2001-2019. Data source: China Metallurgical Industry Planning Institute [73] and Chen, et al. [67].

In short, despite the Scrap/EAF route has obvious advantages in carbon reduction compared to the $\mathrm{BF} / \mathrm{BOF}$ route, it is still constrained by scrap supply and production costs. It is estimated that the cost of Scrap/EAF route is approximately $3500 \mathrm{CNY}$ per tonne of crude steel, comparing with the BF/BOF route's $1000 \mathrm{CNY}$ per tonne of crude steel [74]. In the future, the government and industry should guide and promote the layout of Scrap/EAF steelmaking, and accelerate the establishment of the scrap steel recycling system and the reduction of production costs.

\subsubsection{Promoting Material Efficiency Strategy}

Steel, as a basic engineering material, is reduced from iron ore, then processed in the iron and steel plant, and manufactured into various steel products, finally used to provide service people needed like building and transport, as the iron flow mapped in Figure $12[6,75]$. If steel can be used more efficiently along the supply chain with less steel 
to provide the same level of service, the production of steel will decrease, and thus the $\mathrm{CO}_{2}$ emission associated with the crude steel production will also be reduced [76].

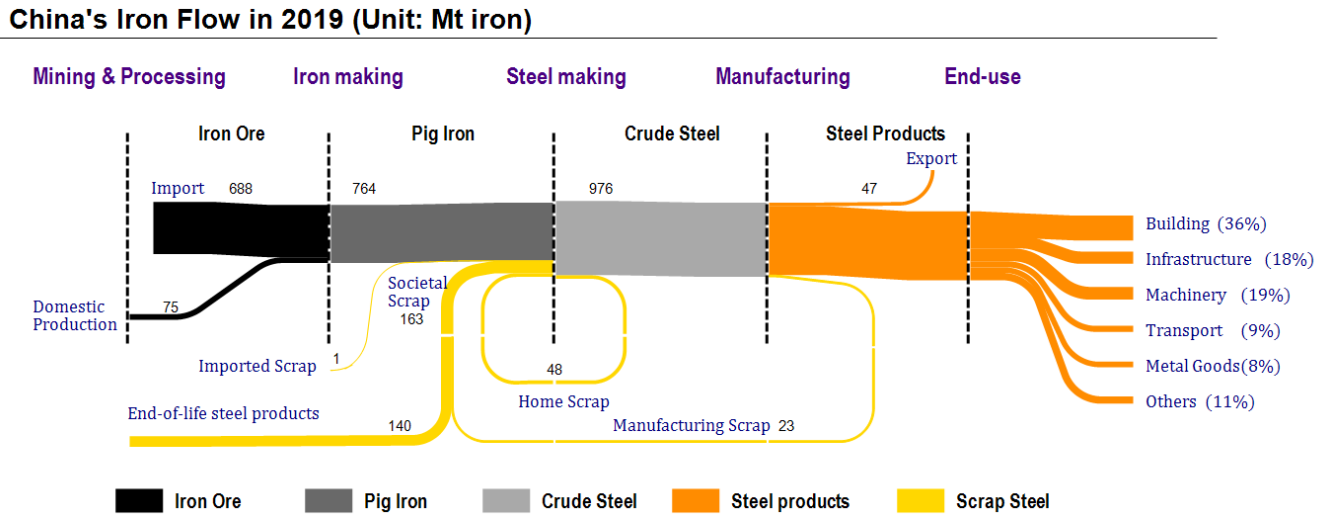

Figure 12. China's iron flow from mining to end-use in 2019. Data source: China Iron and Steel Association [6].

The efficient use of steel along the supply chain is one of the broad material efficiency strategies. The concept of material efficiency was earlier put forward by Allwood, et al. [76], and further developed later [77,78]. It is generally defined as proving material services with less material production, focusing more on the demand side compared with the previous production side strategy of energy efficiency improvement [78]. Material efficiency strategies can be implemented from these following six aspects [78]:

- $\quad$ Light-weight design;

- Reducing yield losses;

- Diverting manufacturing scrap;

- Re-using components;

- $\quad$ Longer-life products;

- $\quad$ More intense use.

Currently, less attention is paid to the material efficiency strategies relative to the energy efficiency strategies in China. IEA estimated $40 \%$ of emission reduction from material efficiency strategies coupled with $21 \%$ energy efficiency potential, for example, improving manufacturing yields and extending building lifetime [5]. The United Nations Environment Programme (UNEP) fully investigated the carbon reduction opportunities on material efficiency associated with residential buildings and passenger cars in G7 countries, for example, $80-100 \%$ reduction can be expected in residential buildings in 2050 by use home more intensively, using less material to design buildings, and using sustainably harvested timber [79]. In China, the government has promoted the "Circular Economy" policy, defined as the reducing, reusing, and recycling activities conducted in the process of production, consumption, and circulation [80], which is similar to the material efficiency strategies. As for the ISI, in fact much policy was oriented towards the "recycle" of scrap steel and it is not comprehensive as the material efficiency strategies [76].

In brief, material efficiency is a potential emission reduction strategy focusing on the demand side of the steel. However, it is subject to some social-economic factors, such as public acceptance and behavioral changes, and requires more in-depth research and long-term policy guidance and promotion.

\subsubsection{Deploying Radical Innovation Technologies}

The actions mentioned above can provide promising and feasible pathways for the carbon reduction in China's ISI, but these are not enough to realize deep decarbonization in China's ISI, let alone net-zero steel. Considering the specific process in the ironand steel-making and some emissions that cannot be avoided, it is expected to deploy radical innovation technologies to constitute avenues for deep emission reductions to net-zero emission. 
Broadly, two categories can be identified for the net-zero emission technologies [5]:

- $\mathrm{CO}_{2}$ management technology. Those keep fossil fuels as the main reducing agent in the ironmaking process, but abate the $\mathrm{CO}_{2}$ emissions that occur, among which the carbon capture, utilization and storage (CCUS) technology is the key representative. - $\mathrm{CO}_{2}$ direct avoidance. Those seek to prevent the generation of $\mathrm{CO}_{2}$ emissions via minimizing the use of fossil carbon, where rising attention is paid to hydrogen-based steelmaking.

The deployment of CCUS in China's ISI is developing forward and projected to expand at speed from the late 2020s. Looking around the world, the only commercial-scale installed CCUS in the iron and steel plant is located in the United Arab Emirates, where CCUS has been successfully installed in the gas-based DRI steel plant. It captures around $0.8 \mathrm{Mt}$ of $\mathrm{CO}_{2}$ per year, and then used $\mathrm{CO}_{2}$ for enhanced oil recovery (EOR). Other than this, world's CCUS deployment in the ISI is basically at a demonstration stage, for example, smelting reduction processes equipped with CCUS, blast furnace equipment with $\mathrm{CO}_{2}$ removal technology [5]. In view of CCUS in China's ISI, it is generally in the stage of small-scale demonstration, such as re-using captured carbon in the steelmaking process to reduce $5-10 \%$ of $\mathrm{CO}_{2}$ emissions in the Shougang Group [81]. To the carbon neutrality by 2060, the carbon reduction demand for the CCUS in China's iron and steel industry is estimated to reach $90-110 \mathrm{Mt}$ per year [81]. The cost of CCUS technology is the main factor affecting its large-scale deployment, which is estimated to be reduced in the future with advances in technology. It is expected that, as listed in Table 6, by 2030, the cost of China's integrated CCUS process will be $310-770 \mathrm{CNY} / \mathrm{tCO}_{2}$, and will gradually drop to $140-410 \mathrm{CNY} / \mathrm{tCO}_{2}$ (250 km transportation distance) [81].

Table 6. Cost projection of China's CCUS technology from 2025 to 2060. Data source: Cai, et al. [81].

\begin{tabular}{|c|c|c|c|c|c|c|}
\hline \multicolumn{2}{|c|}{ Process } & 2025 & 2030 & 2040 & 2050 & 2060 \\
\hline \multirow{3}{*}{$\begin{array}{l}\text { Carbon } \\
\text { capture } \\
\text { (CNY/t) }\end{array}$} & Pre-combustion & $100-180$ & $90-130$ & $50-70$ & $30-50$ & $20-40$ \\
\hline & Post-combustion & $230-310$ & 190-280 & $100-180$ & $80-150$ & $70-120$ \\
\hline & $\begin{array}{l}\text { Oxygen enriched } \\
\text { combustion }\end{array}$ & $300-480$ & $160-390$ & $110-230$ & $90-150$ & $80-130$ \\
\hline \multirow{2}{*}{$\begin{array}{l}\text { Transportation } \\
(\mathrm{CNY} /(\mathrm{t} \cdot \mathrm{km}))\end{array}$} & Road & $0.9-1.4$ & $0.8-1.3$ & $0.6-1.1$ & $0.5-1.1$ & $0.5-1$ \\
\hline & Carbon storage $(\mathrm{CNY} / \mathrm{t})$ & $\begin{array}{c}0.8 \\
50-60\end{array}$ & $\begin{array}{c}0.7 \\
40-50\end{array}$ & $\begin{array}{c}0.5 \\
30-35\end{array}$ & $\begin{array}{c}0.45 \\
25-30\end{array}$ & $\begin{array}{c}0.4 \\
20-25\end{array}$ \\
\hline
\end{tabular}

The hydrogen-based steelmaking is regarded as one of the most promising breakthrough technologies for the achievement of net-zero steel in China [82]. Generally, hydrogen can be generated by these three ways:

- Grey hydrogen: Hydrogen produced from gas or coal. It is still with large $\mathrm{CO}_{2}$ emissions.

- $\quad$ Blue hydrogen: Hydrogen produced from gas or cola equipped with CCUS. This hydrogen will result in a radical emission reduction.

- Green hydrogen: Hydrogen generated from renewable energy sources, such as hydrogen produced from the electrolysis of water with renewable electricity.

Looking around the world, in Europe, the DRI route using hydrogen generated from Green hydrogen is considered as a key solution to enable the production of high purity steel without $\mathrm{CO}_{2}$ emissions [83]. In Japan, the recirculation of reformed hydrogen-rich off-gas to replace cokes in the blast furnace has been explored for many years, represented by the COURSE50 project [48]. In China, the Baowu Group, the largest steel producer in the world, has set up a pilot project of the hydrogen-rich carbon circulation in blast furnaces in 2021, expected to reduce $30 \%$ carbon emissions [84]. At present, China is a 
major hydrogen producing country, and most of the hydrogen energy is produced from coal. In the future, hydrogen produced from renewable energy sources is expected to be the dominant production route. However, the production of green hydrogen in China is still constrained by high costs. As shown in Figure 13, green hydrogen currently costs about three times as much as grey hydrogen, and will not be as cheap as grey hydrogen until around 2040 [85].

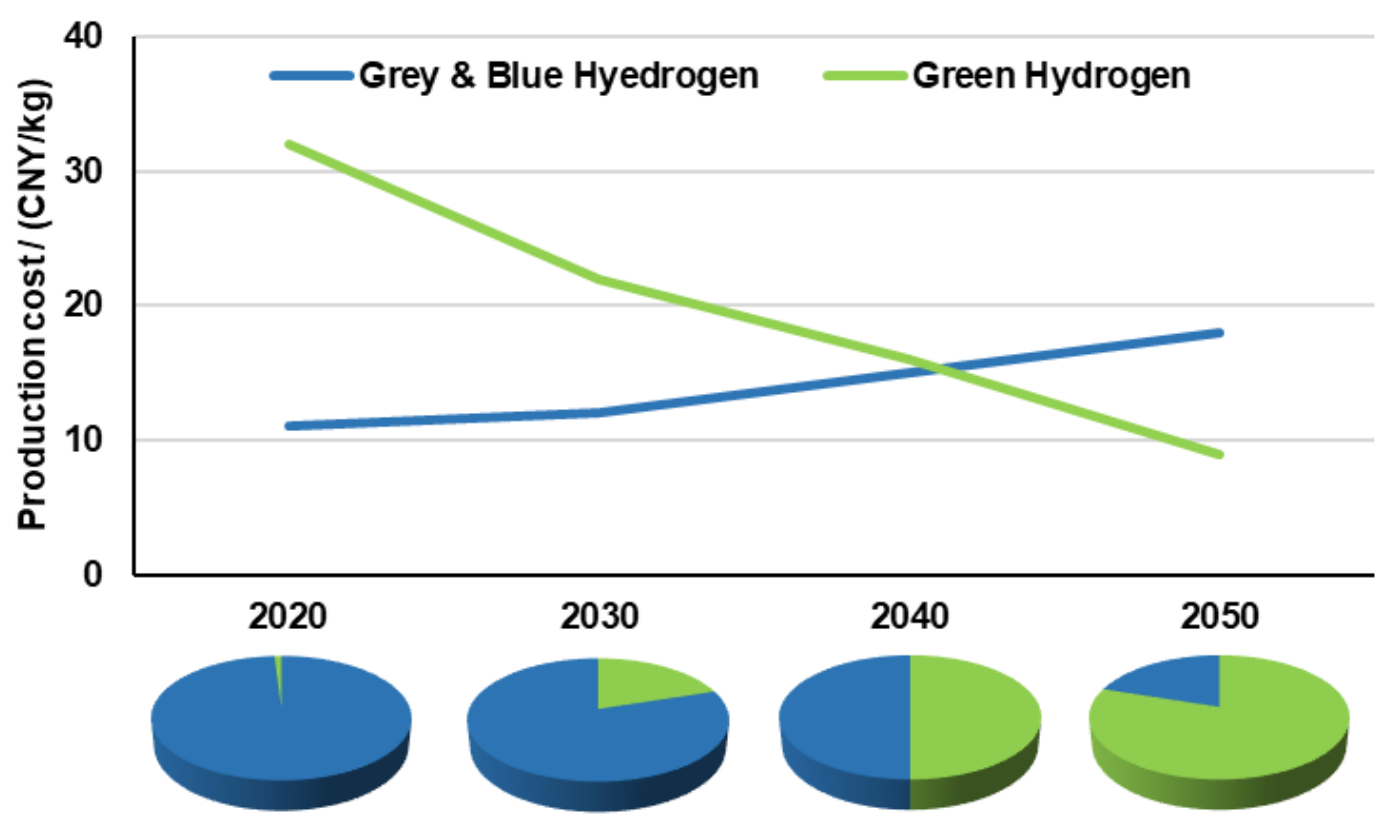

Figure 13. Projection of cost and supply structure of China's hydrogen production. Data source: Deloitte [85] and Zhang [82].

In a word, there is no right answer for the deployment of radical innovation technologies in China's and also the world's ISI. It is still faced with great challenges and uncertainties, such as the technology readiness level and high costs.

\section{Policy Recommendations}

China's ISI is expected to achieve complete decarbonization with such a short period of at most 40 years. This is almost impossible for an industry to develop itself, and the government will play a central role in this low-carbon development.

To the carbon neutrality in China's ISI, this paper has discussed four key actions available for China's ISI in the above sections, as shown in Figure 14. Based on these discussions, main policy implementation can be suggested for the government:

- Fully exploiting the potential for energy efficiency in the short term. There is still a certain gap between China's energy consumption per ton of steel and the world advanced level, which can be further reduced by means of technology improvement, process optimization, waste energy recovery, and smart digital management. Meanwhile, backward production technologies still exist in China [86], and the elimination of these backward production capacities should be accelerated.

- Promoting the layout of Scrap/EAF steel production capacity. The government should adopt policy incentives to ensure the cost advantages of the Scrap/EAF route so that it can compete with the existing BF/BOF route, such as subsidies to the electricity price. Moreover, the government should support the industry to establish a centralized and standardized scrap recycling system to ensure the supply of scrap steel for the Scrap/EAF, for example, mandate recycling for cars, houses, and buildings.

- Accelerating the efficient use of steel. The efficient use of steel is important for increasing the value of each ton of steel and slowing down demand growth. Work can be done by the government including coordinating recycling networks, modify 
design regulation towards lightweight, incentives for refurbishment building to extend lifetimes, and advocating the lifestyle of sharing economy.

- Financial support for the innovative net-zero technologies. Financial support from the government is important for the innovation of these net-zero technologies, from lab-scale experiments and pilots, to demonstrations. For example, continuous financial support should be given to hydrogen-based steelmaking, since it is still in the stage of prototype and pilot.

- Including the ISI in the carbon trading market. At present, China has included the power industry in the carbon trading market, and in the future, the ISI will be further included. The carbon trading market will force the whole industry to carry out the low-carbon transition and stimulate the steel-producer's willingness for low-carbon development.

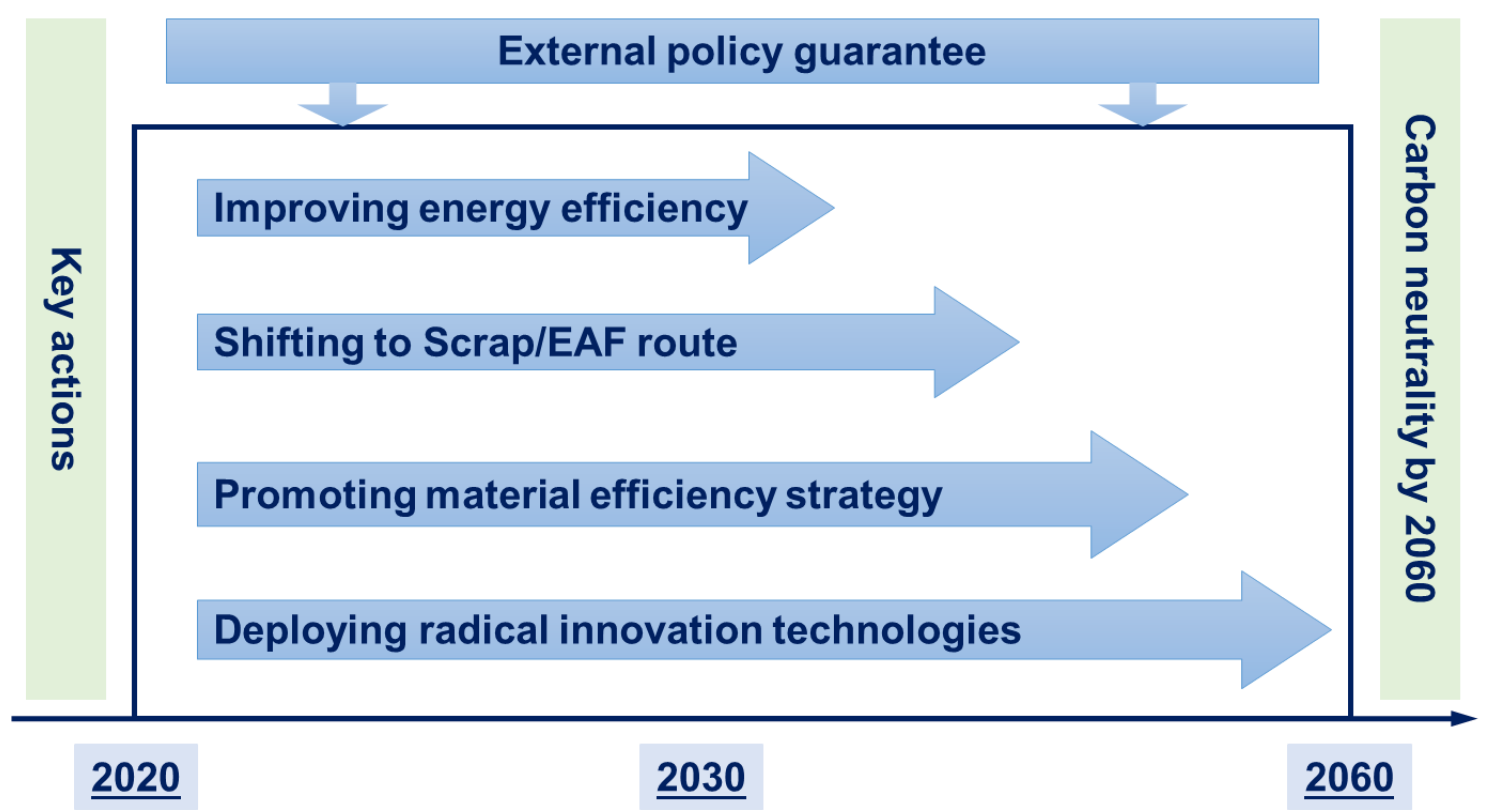

Figure 14. Key actions for the carbon neutrality in China's ISI by 2060.

\section{Conclusions}

Steel is a good supporter for the developing economy in China, but also a key contributor to the attainment of China's $\mathrm{CO}_{2}$ reduction target as a typical energy and emissionintensive sector. It is such challenging work for China's ISI to achieve deep decarbonization within just 40 years by 2060 .

To better guide China's policymaking focusing on the low-carbon development of the ISI, this paper first reviewed the low-carbon development technology roadmaps around the world, then evaluated the potential of those key decarbonization actions available for China's decarbonization in the ISI, and finally provided policy recommendations and future research priorities. In the future, four key actions can be addressed: Improving energy efficiency, shifting to Scrap/EAF route, promoting material efficiency strategy, and deploying radical innovation technologies like CCUS and hydrogen-based steelmaking. Especially, the potential of energy efficiency improvements is limited in the long term, and the potential coupled with material efficiency strategies needs to be further explored in China. Most importantly, the government is expected to play a central role in this transition progress, including continuous financial support and policy guidance.

For the next-step work, it is expected to conduct quantitative modelling analysis and build scenarios to explore the long-term low-carbon development pathway for China's ISI, focusing on the configuration of the four key actions mentioned in this paper $[87,88]$. Then, the co-benefits and trade-offs underlying the transition process can be further evalu- 
ated, such as co-benefits between energy efficiency strategy and material efficiency strategy [89], and coordination in different regions [90]. Additionally, the social-economic factors and stakeholders affecting the low-carbon transition of the ISI should be further investigated [91].

Author Contributions: Conceptualization, Y.L. and L.M.; methodology, Y.L.; data curation, Y.L. and H.Y.; writing-original draft preparation, Y.L.; writing - review and editing, L.M. and H.Y.; supervision, L.M.; funding acquisition, Z.L. and W.N. All authors have read and agreed to the published version of the manuscript.

Funding: This research was funded by the National Natural Science Foundation of China (grant number 71690245). The authors gratefully acknowledge the support of B.P. in the form of Phase II and Phase III Collaboration between B.P. and Tsinghua University, and the support of the Tsinghua-Rio Tinto Joint Research Centre for Resources, Energy, and Sustainable Development.

Institutional Review Board Statement: Not applicable.

Informed Consent Statement: Not applicable.

Data Availability Statement: All data are available in the public domain.

Conflicts of Interest: The authors declare no conflict of interest.

\section{References}

1. UNFCCC. The Paris Agreement. Available online: https://unfccc.int/process-and-meetings/the-paris-agreement/the-parisagreement (accessed on 13 October 2021).

2. BP. BP Statistical Review of World Energy 2021; BP: London, UK, 2021.

3. Ministry of Foreign Affairs of the People's Republic of China. Xi Jinping Delivers an Important Speech at the General Debate of the 75th Session of the United Nations (UN) General Assembly. Available online: https://www.fmprc.gov.cn/mfa_eng/zxxx_66 2805/t1817766.shtml (accessed on 15 April 2021).

4. Ekdahl, A. Climate Change and the Production of Iron and Steel: An Industry View; World Steel Association: Brussels, Belgium, 2021.

5. International Energy Agency. Iron and Steel Technology Roadmap; IEA: Paris, France, 2020.

6. China Iron and Steel Association. China Steel Yearbook 2020; China Iron and Steel Association: Beijing, China, 2020.

7. World Steel Association. World Steel Statistical Yearbook 2020; World Steel Association: Brussels, Belgium, 2020.

8. Yang, H.; Ma, L.; Li, Z. A Method for Analyzing Energy-Related Carbon Emissions and the Structural Changes: A Case Study of China from 2005 to 2015. Energies 2020, 13, 2076. [CrossRef]

9. Long, W.; Wang, S.; Lu, C.; Xue, R.; Liang, T.; Jiang, N.; Zhang, R. Quantitative Assessment of Energy Conservation Potential and Environmental Benefits of an Iron and Steel Plant in China. J. Clean. Prod. 2020, 273, 123163. [CrossRef]

10. He, K.; Wang, L. A Review of Energy Use and Energy-Efficient Technologies for the Iron and Steel Industry. Renew. Sustain. Energy Rev. 2017, 70, 1022-1039. [CrossRef]

11. Bo, X.; Jia, M.; Xue, X.; Tang, L.; Mi, Z.; Wang, S.; Cui, W.; Chang, X.; Ruan, J.; Dong, G.; et al. Effect of Strengthened Standards on Chinese Ironmaking and Steelmaking Emissions. Nat. Sustain. 2021, 4, 811-820. [CrossRef]

12. Zhou, K.; Yang, S. Emission Reduction of China'S Steel Industry: Progress and Challenges. Renew. Sustain. Energy Rev. 2016, 61, 319-327. [CrossRef]

13. Zeng, S.; Zhou, Y. Foreign Direct Investment's Impact on China's Economic Growth, Technological Innovation and Pollution. Int. J. Environ. Res. Public Health 2021, 18, 2839. [CrossRef] [PubMed]

14. Zhang, Q.; Wei, Z.; Ma, J.; Qiu, Z.; Du, T. Optimization of Energy Use with $\mathrm{CO}_{2}$ Emission Reducing in an Integrated Iron and Steel Plant. Appl. Therm. Eng. 2019, 157, 113635. [CrossRef]

15. Chen, Q.; Gu, Y.; Tang, Z.; Wei, W.; Sun, Y. Assessment of Low-Carbon Iron and Steel Production with $\mathrm{CO}_{2}$ Recycling and Utilization Technologies: A Case Study in China. Appl. Energy 2018, 220, 192-207. [CrossRef]

16. Nechifor, V.; Calzadilla, A.; Bleischwitz, R.; Winning, M.; Tian, X.; Usubiaga, A. Steel in a Circular Economy: Global Implications of a Green Shift in China. World Dev. 2020, 127, 104775. [CrossRef]

17. Ren, L.; Zhou, S.; Peng, T.; Ou, X. A Review of $\mathrm{CO}_{2}$ Emissions Reduction Technologies and Low-Carbon Development in the Iron and Steel Industry Focusing on China. Renew. Sustain. Energy Rev. 2021, 143, 110846. [CrossRef]

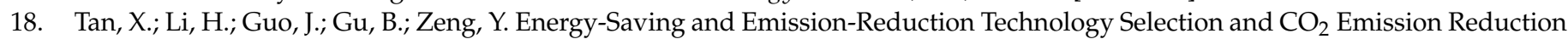
Potential of China's Iron and Steel Industry under Energy Substitution Policy. J. Clean. Prod. 2019, 222, 823-834. [CrossRef]

19. Phaal, R.; Farrukh, C.J.; Probert, D.R. Technology Roadmapping-A Planning Framework for Evolution and Revolution. Technol. Forecast. Soc. Chang. 2004, 71, 5-26. [CrossRef]

20. Galvin, R. Science Roadmaps. Science 1998, 280, 803. [CrossRef]

21. Linton, J.D. Determining Demand, Supply, and Pricing for Emerging Markets Based on Disruptive Process Technologies. Technol. Forecast. Soc. Chang. 2004, 71, 105-120. [CrossRef] 
22. Petrick, I.J.; Echols, A.E. Technology Roadmapping in Review: A Tool for Making Sustainable New Product Development Decisions. Technol. Forecast. Soc. Chang. 2004, 71, 81-100. [CrossRef]

23. IEA. Energy Technology Roadmaps: A Guide to Development and Implementation; IEA: Paris, France, 2014.

24. Gonzalez-Salazar, M.A.; Venturini, M.; Poganietz, W.-R.; Finkenrath, M.; Kirsten, T.; Acevedo, H.; Spina, P.R. Development of a Technology Roadmap for Bioenergy Exploitation including Biofuels, Waste-to-Energy and Power Generation \& CHP. Appl. Energy 2016, 180, 338-352.

25. Hao, H.; Cheng, X.; Liu, Z.; Zhao, F. China's Traction Battery Technology Roadmap: Targets, Impacts and Concerns. Energy Policy 2017, 108, 355-358. [CrossRef]

26. Assunção, L.R.C.; Mendes, P.A.S.; Matos, S.; Borschiver, S. Technology Roadmap of Renewable Natural Gas: Identifying Trends for Research and Development to Improve Biogas Upgrading Technology Management. Appl. Energy 2021, 292, 116849. [CrossRef]

27. Wei, X.; Qiu, R.; Liang, Y.; Liao, Q.; Klemeš, J.J.; Xue, J.; Zhang, H. Roadmap to Carbon Emissions Neutral Industrial Parks: Energy, Economic and Environmental Analysis. Energy 2022, 238, 121732. [CrossRef]

28. Phaal, R.; Muller, G. An Architectural Framework for Roadmapping: Towards Visual Strategy. Technol. Forecast. Soc. Chang. 2009, 76, 39-49. [CrossRef]

29. Quader, M.A.; Ahmed, S.; Ghazilla, R.A.R.; Ahmed, S.; Dahari, M. A Comprehensive Review on Energy Efficient CO 2 Breakthrough Technologies for Sustainable Green Iron and Steel Manufacturing. Renew. Sustain. Energy Rev. 2015, 50, 594-614. [CrossRef]

30. Hasanbeigi, A.; Arens, M.; Price, L. Alternative Emerging Ironmaking Technologies For Energy-Efficiency And Carbon Dioxide Emissions Reduction: A Technical Review. Renew. Sustain. Energy Rev. 2014, 33, 645-658. [CrossRef]

31. Napp, T.; Gambhir, A.; Hills, T.; Florin, N.; Fennell, P. A Review of the Technologies, Economics and Policy Instruments for Decarbonising Energy-Intensive Manufacturing Industries. Renew. Sustain. Energy Rev. 2014, 30, 616-640. [CrossRef]

32. Yellishetty, M.; Mudd, G.; Ranjith, P.; Tharumarajah, A. Environmental Life-Cycle Comparisons of Steel Production and Recycling: Sustainability Issues, Problems and Prospects. Environ. Sci. Policy 2011, 14, 650-663. [CrossRef]

33. Zhang, Q.; Xu, J.; Wang, Y.; Hasanbeigi, A.; Zhang, W.; Lu, H.; Arens, M. Comprehensive Assessment of Energy Conservation and $\mathrm{CO}_{2}$ Emissions Mitigation in China's Iron and Steel Industry Based on Dynamic Material Flows. Appl. Energy 2018, 209, 251-265. [CrossRef]

34. World Steel Association. World Steel Statistical Yearbook Collections 1978 to 2020. Available online: https: / /www.worldsteel. org/steel-by-topic/statistics/steel-statistical-yearbook.html (accessed on 22 September 2021).

35. European Commission. Climate Action. Available online: https://ec.europa.eu/clima/policies/strategies/2050_en (accessed on 3 October 2021).

36. The Government of the Republic of Korea. Carbon Neutral Strategy of the Republic of Korea. Available online: https:/ / unfccc. int/sites/default/files/resource/LTS1_RKorea.pdf (accessed on 24 September 2021).

37. The Government of Japan. Carbon Neutrality. Available online: https://www.japan.go.jp/key_policies_of_the_suga_cabinet/ carbon_neutrality.html (accessed on 26 September 2021).

38. The Energy and Resources Institute (TERI) India. Towards a Low Carbon Steel Sector: Overview of the Changing Market, Technology and Policy Context for Indian Steel; The Energy and Resources Institute (TERI) India: New Delhi, India, 2020.

39. ArcelorMittal. ArcelorMittal Launches XCarb ${ }^{\mathrm{TM}}$, Signalling Its Commitment to Producing Carbon Neutral Steel. Available online: https:/ / corporate.arcelormittal.com/media/press-releases/arcelormittal-launches-xcarb-signalling-its-commitmentto-producing-carbon-neutral-steel\#\%E3\%80\%91 (accessed on 27 September 2021).

40. TATA STEEL. Sustainability-TATA STEEL. Available online: https://www.tatasteel.com/tata-steel-brochure-19-20/ sustainability.html (accessed on 27 September 2021).

41. Argus. India's JSW Steel Sets 2030 Carbon Emissions Target. Available online: https://www.argusmedia.com/en/news/224714 7-indias-jsw-steel-sets-2030-carbon-emissions-target (accessed on 27 September 2021).

42. Ministry of New and Renewable Energy, Government of India. Hydrogrn Energy. Available online: https://mnre.gov.in/newtechnologies/hydrogen-energy (accessed on 27 September 2021).

43. Ministry of the Environment Japan. Greenhouse Gas Inventory Office of Japan 2020; Ministry of the Environment Japan: Tokyo, Japan, 2020.

44. Japan Iron and Steel Federation (JISF). Basic Policy of the Japan Steel Industry on 2050 Carbon Neutrality Aimed by the Japanese Government. Available online: https://www.jisf.or.jp/en/activity/climate/index.html (accessed on 26 September 2021).

45. Nippon Steel Corporation. Nippon Steel Carbon Neutral Vision 2050-A Challenge of Zero-Carbon Steel; Nippon Steel Corporation: Tokyo, Japan, 2021.

46. JEF Holdings, Inc. Climate Change Mitigation of JEF Group. Available online: https://www.jfe-holdings.co.jp/en/csr/ environment/climate/ (accessed on 26 September 2021).

47. Li, H.-W.; Nishimiya, N. Insight from Japan's Hydrogen Strategy and Activities. Engineering 2021, 7, 722-725. [CrossRef]

48. COURSE50 Project Group. COURSE50 Project. Available online: https://www.course50.com/en/message/ (accessed on 26 September 2021).

49. The White House. Fact Sheet: President Biden Sets 2030 Greenhouse Gas Pollution Reduction Target Aimed at Creating GoodPaying Union Jobs and Securing U.S. Leadership on Clean Energy Technologies. Available online: https://www.whitehouse.gov/ briefing-room/statements-releases /2021/04/22/fact-sheet-president-biden-sets-2030-greenhouse-gas-pollution-reduction- 
target-aimed-at-creating-good-paying-union-jobs-and-securing-u-s-leadership-on-clean-energy-technologies / (accessed on 29 September 2021).

50. Feldmann, J.; Kennedy, K. Toward a Tradable, Low-Carbon Product Standard for Steel: Policy Design Considerations for the United States; World Resources Institute: Washington, DC, USA, 2021.

51. Nucor Corporation. Our Greenhouse Gas Reduction Target Strategy. Available online: https://www.nucor.com/greenhouse-gasreduction-target-strategy/ (accessed on 29 September 2021).

52. United Stated Steel Corporation. Environment_Greenhouse Gas Emission; United Stated Steel Corporation: Pittsburgh, PA, USA, 2021.

53. Byun, W. Steel/Metal Industry: Movement Towards Carbon Neutrality Begins in Earnest. Available online: http://www. businesskorea.co.kr/news/articleView.html?idxno=57179 (accessed on 1 October 2021).

54. POSCO. POSCO Pledges to Achieve Carbon Neutrality by 2050 and Lead Low Carbon Society. Available online: https: / / en.wikipedia.org/wiki/List_of_steel_producers (accessed on 1 October 2021).

55. Stangarone, T. South Korean Efforts to Transition to a Hydrogen Economy. Clean Technol. Environ. Policy 2021, $23,509-516$. [CrossRef]

56. Federal Ministry for the Environment, Nature Conservation and Nuclear Safety. Revised Climate Change Act Sets Out Binding Trajectory towards Climate Neutrality by 2045. Available online: https: / /www.bmu.de/en/pressrelease/revised-climate-changeact-sets-out-binding-trajectory-towards-climate-neutrality-by-2045 (accessed on 27 September 2021).

57. The Federal Government. For a Strong Steel Industry in Germany and Europe-The Steel Action Concept; The Federal Government: Berlin, Germany, 2020.

58. The Federal Government. The National Hydrogen Strategy; The Federal Government: Berlin, Germany, 2020.

59. ThyssenKrupp AG. Green Hydrogen for Green Steel: Paving the Way to Hydrogen Valley. Available online: https: / / engineered. thyssenkrupp.com/en/green-hydrogen-for-green-steel/ (accessed on 14 October 2021).

60. China Iron and Steel Association. China Steel Yearbook 1985; China Iron and Steel Association: Beijing, China, 1985.

61. National Bureau of Statistics of China. China Statistical Yearbook 2020; National Bureau of Statistics of China: Beijing, China, 2020.

62. World Steel Association. Global Crude Steel Output Decreases by 0.9\% in 2020. Available online: https://www.worldsteel.org/ media-centre/press-releases/2021/Global-crude-steel-output-decreases-by-0.9--in-2020.html (accessed on 5 October 2021).

63. National Bureau of Statistics of China. China Energy Statistical Yearbook 2020; National Bureau of Statistics of China: Beijing, China, 2020.

64. China Baowu Group. Strive to "Carbon Peak" in 2023 and Achieve "Carbon Neutrality" in 2050-China Baowu Group, the World's Largest Steel Company, Releases Carbon Emission Reduction Declaration. Available online: http:/ / www.baowugroup. com/media_center/news_detail/201868 (accessed on 15 April 2021).

65. HBIS Group. HBIS Announces Its Low Carbon \& Green Development Action Plan. Available online: https://www.hbisco.com/ site/en/groupnewssub/info/2021/15999.html (accessed on 4 October 2021).

66. China Metallurgical Industry Planning Institute. Action Plan for the Carbon Peak and Carbon Reduction of the Iron and Steel Industryare Taking Shape. Available online: http://www.mpi1972.com/xwzx/xyyw_451/202103/t20210330_95674.html (accessed on 9 November 2021). (In Chinese).

67. Chen, W.; Yin, X.; Ma, D. A Bottom-Up Analysis of China's Iron and Steel Industrial Energy Consumption and $\mathrm{CO}_{2}$ Emissions. Appl. Energy 2014, 136, 1174-1183. [CrossRef]

68. Zhang, Q.; Zhang, W.; Wang, Y.; Xu, J.; Cao, X. Potential of Energy Saving and Emission Reduction and Energy Efficiency Improvement of China's Steel Industry. Iron Steel 2019, 54, 7-14. (In Chinese)

69. Li, Y.; Zhu, L. Cost of Energy Saving and $\mathrm{CO}_{2}$ Emissions Reduction in China's Iron and Steel Sector. Appl. Energy 2014, 130, 603-616. [CrossRef]

70. Mickinsey. The Growing Importance of Steel Scrap in China; Mickinsey: Chicago, IL, USA, 2017.

71. China Iron and Steel Association. China Steel Yearbook 2019; China Iron and Steel Association: Beijing, China, 2019.

72. China Iron and Steel Association. China Steel Yearbook 2016; China Iron and Steel Association: Beijing, China, 2016.

73. China Metallurgical Industry Planning and Research Institute. Improve the Efficiency of Scrap Steel Utilization and Promote the Low-Carbon Development of the Steel Industry. Available online: http:/ /www.mpi1972.com/xwzx/tzgg/202103/t20210305_95 371.html (accessed on 6 October 2021). (In Chinese).

74. Chen, J.; Li, S.; Li, X.; Li, Y. The Road to Zero Carbon for Chinese Steel under Carbon Neutrality Goal; Rocky Mountain Institute: Beijing, China, 2021.

75. Wu, J.; Yang, J.; Ma, L.; Li, Z.; Shen, X. A System Analysis of the Development Strategy of Iron Ore in China. Resour. Policy 2016, 48, 32-40. [CrossRef]

76. Allwood, J.; Ashby, M.F.; Gutowski, T.G.; Worrell, E. Material Efficiency: A White Paper. Resour. Conserv. Recycl. 2011, 55, 362-381. [CrossRef]

77. Allwood, J.M.; Cullen, J.M.; Milford, R.L. Options for Achieving a 50\% Cut in Industrial Carbon Emissions by 2050. Environ. Sci. Technol. 2010, 44, 1888-1894. [CrossRef] [PubMed]

78. Allwood, J.M.; Ashby, M.F.; Gutowski, T.G.; Worrell, E. Material Efficiency: Providing Material Services with Less Material Production. Philos. Trans. R. Soc. A Math. Phys. Eng. Sci. 2013, 371, 20120496. [CrossRef] [PubMed] 
79. Hertwich, E.; Lifset, R.; Pauliuk, S.; Heeren, N. Resource Efficiency and Climate Change: Material Efficiency Strategies for a Low-Carbon Future; United Nations Environment Programme: Nairobi, Kenya, 2020.

80. Ghisellini, P.; Cialani, C.; Ulgiati, S. A Review on Circular Economy: The Expected Transition to a Balanced Interplay of Environmental and Economic Systems. J. Clean. Prod. 2016, 114, 11-32. [CrossRef]

81. Cai, B.; Li, Q.; Zhang, X. Annual Report on Carbon Capture, Utilization and Storage (CCUS) in China (2021); Institute of Environmental Planning, Ministry of Ecology and Environment: Beijing, China, 2021. (In Chinese)

82. Zhang, X. The Development Trend of and Suggestions for China's Hydrogen Energy Industry. Engineering 2021, 7, 719-721. [CrossRef]

83. Mickinsey. Decarbonization Challenge for Steel; Mickinsey: Düsseldorf, Germany, 2020.

84. BJX News. Steel Industry Opens Hydrogen Age! Available online: https://chuneng.bjx.com.cn/news/20210318/1142436.shtml (accessed on 5 November 2021). (In Chinese).

85. Deloitte. Creating a Viable Hydrogen Economy-A Future of Energy Point of View on Hydrogen; Deloitte: Beijing, China, 2021.

86. Lin, Y.; Chong, C.; Ma, L.; Li, Z.; Ni, W. Analysis of Changes in the Aggregate Exergy Efficiency of China's Energy System from 2005 to 2015. Energies 2021, 14, 2304. [CrossRef]

87. Li, T.; Liu, P.; Li, Z. Quantitative Relationship between Low-Carbon Pathways and System Transition Costs Based on a MultiPeriod and Multi-Regional Energy Infrastructure Planning Approach: A Case Study of China. Renew. Sustain. Energy Rev. 2020, 134, 110159. [CrossRef]

88. Chen, S.; Liu, P.; Li, Z. Low Carbon Transition Pathway of Power Sector with High Penetration of Renewable Energy. Renew. Sustain. Energy Rev. 2020, 130, 109985. [CrossRef]

89. Milford, R.L.; Pauliuk, S.; Allwood, J.M.; Müller, D.B. The Roles of Energy and Material Efficiency in Meeting Steel Industry CO 2 Targets. Environ. Sci. Technol. 2013, 47,3455-3462. [CrossRef] [PubMed]

90. Zhao, Y.; Ma, L.; Li, Z.; Ni, W. The Development of Regional Smart Energy Systems in the World and China: The Concepts, Practices, and a New Perspective. Wiley Interdiscip. Rev. Data Min. Knowl. Discov. 2021, 11, e1409. [CrossRef]

91. Yang, H.; Li, X.; Ma, L.; Li, Z. Using System Dynamics to Analyse Key Factors Influencing China's Energy-Related $\mathrm{CO}_{2}$ Emissions and Emission Reduction Scenarios. J. Clean. Prod. 2021, 320, 128811. [CrossRef] 